\title{
ASSESSING MISMATCHES IN ECOSYSTEM SERVICES PROFICIENCY ACROSS THE URBAN FABRIC OF PORTO (PORTUGAL): THE INFLUENCE OF STRUCTURAL AND SOCIOECONOMIC VARIABLES
}

\section{Marisa S. GRAÇA ${ }^{\text {a, b* }}{ }^{*}$, João F. GONÇALVES ${ }^{\text {a, b }}$, Paulo J. M. ALVES ${ }^{\text {a }}$, David J. NOWAK $^{\mathrm{c}}$, Robert HOEHN ${ }^{\mathrm{c}}$, Alexis ELLIS ${ }^{\mathrm{d}}$, Paulo FARINHA-MARQUES ${ }^{\mathrm{a}, \mathrm{b}}$, Mario CUNHA $^{\text {b, e }}$.}

${ }^{\text {a }}$ Research Center in Biodiversity and Genetic Resources (CIBIO/InBIO) - University of Porto, Campus Agrário de Vairão, Rua Padre Armando Quintas, nº 7, 4485-661 Vairão, Portugal

${ }^{\mathrm{b}}$ Faculty of Sciences of the University of Porto, Rua do Campo Alegre, s/n, 4169-007 Porto, PORTUGAL

${ }^{c}$ Northern Research Station, USDA Forest Service, 5 Moon Library, SUNY-ESF, Syracuse, New York, USA, 13210

${ }^{\mathrm{d}}$ The Davey Institute, The Davey Tree Expert Company, 1500 N. Mantua Street, P.O. Box 5193, Kent, Ohio 44240

${ }^{\mathrm{e}}$ Geo-Space Sciences Research Centre (CICGE), University of Porto, Departamento de Matemática, Rua do Campo Alegre nº 687, 4169-007 Porto, Portugal

* Corresponding author

E-mail: graca.marisa@fc.up.pt

Phone number: +351252660411

Keywords (3-6)

Urban Ecosystem Services; Regulating Ecosystem Services; Urban Planning; Urban vegetation; Socioeconomic inequity. 


\section{Introduction}

According to UN estimates, it is expected that the world population living in cities will exceed 66\% in 2050 (United Nations, 2014). The complex and intense interaction of ecological and socioeconomic systems shaping cities has highlighted the need to foster an interdisciplinary approach to urban issues integrating Natural and Social Sciences (Alberti et al., 2003). Recent research has also stressed the role of urban ecosystems in providing vital services to city dwellers, and the need to embody ecosystem services in urban planning practice (Ahern et al., 2014; Colding, 2011 ). Ecosystem services (ES) has come to light as one of the most widespread concepts of Ecology in recent years, and refers to the benefits human populations derive from ecosystems (MEA, 2005). Research on ES and the socio-ecological factors that influence their proficiency is essential to allow cities to adopt policies that lead to resource-efficient strategies (Andersson et al., 2007) and greater resilience, which supports ecological, economic and social sustainability (Berkes, 2003; McPhearson et al., 2015). Some benefits generated by ecosystems need to be delivered locally to be enjoyed by city inhabitants, such as clean air, runoff regulation, microclimate regulation, erosion control, storm protection and recreation. Urban green areas provide a wide range of these local ecosystem services and thus become very important to sustain human wellbeing in cities (Bolund \& Hunhammar, 1999). However, many obstacles prevent ES from being widely operational in urban planning practice. Studies and assessments of urban ES many times lack operability for professionals and planners because they are not developed at a scale relevant for planning and policy decisions (Hölzinger et al., 2014) or do not address the transfer of knowledge and methods in an accessible way to stakeholders, thus providing limited clues for planning and management (Haase et al., 2014). In addition, key concepts remain controversial (Fisher et al., 2009; Hermann et al., 2011), and the lack of consistent methodologies for quantifying, visualizing and valuing ES poses challenges (Seppelt et al., 2011).

Urban ecosystems differ from other ecosystems because they are intensely dominated by human beings, being characterized by high fragmentation and heterogeneity levels. They raise additional questions to researchers and are still poorly understood compared with other types of ecosystems (Gomez-Baggethun \& Barton, 2013). Services such as air filtration, thermal regulation, contribution to the perception of the urban environment, sense of place or social cohesion are difficult to assess, and knowledge about the local ES delivery is frequently scarce or not suitable for planners. This knowledge should inform the setting of goals before urban interventions, but usually it cannot be generated within the traditional timeframe of project planning due to time and resource constraints. Because of such difficulties, the structural or functional aspects that sustain urban ES are usually not taken into account in an objective way in the planning and design process, particularly regarding green spaces. Recent investigations suggest a relationship between type and management of green areas and ES provided (Andersson et al., 2007), and that variation in the abundance and layout of vegetation in different types of urban green spaces originates differences in ES delivered (Hayek et al., 2010). There is also evidence of relationships between plant functional diversity and ecosystem processes (Díaz \& Cabido, 2001). However, properties like functional redundancy of species are not traditionally taken into account in professional practice regarding planning, design and management of urban green spaces. In addition, biodiversity in green spaces may affect the provision of many services that affect the health and wellbeing of city dwellers, but it is many times seen as having little impact in the urban context, and providing few direct and essential 
benefits for human beings (Ahern, 2013). Even promoting biodiversity per se raises questions about how this can be accomplished, because emerging evidence is revealing that, for example, species richness alone probably does not drive ecosystem function (Cadotte et al., 2011).

Delivery of ES is also greatly determined by socioeconomic factors and reflects urban patterns. Examples include dissimilarities of provision of urban green spaces by demographic variables like immigrant status and age (Kabisch \& Haase, 2014), relationships between public urban forest structure and socioeconomic strata (Escobedo et al., 2006), increased exposure towards urban flooding according to indices of social segregation (Romero et al., 2012), spatial variation in urban plant diversity across low to high-income areas (Hope et al., 2003), inequity in the spatial distribution of public right-of-way street trees (Landry \& Chakraborty, 2009) and the impact of lifestyle behavior and housing characteristics in species composition and configuration (Grove et al., 2006). However, to our knowledge these findings have seldom been translated into objective guidelines that can help to inform planning and design practice.

All these considerations could mean that it is not enough to include green areas in urban settings, without addressing their specific characteristics and ability to sustain the well-being of city's inhabitants. Urban green areas can be designed to contribute for the provision of specific ES such as microclimate regulation (Jenerette et al., 2011), mental wellbeing (Kuo, 2001), physical and psychological health (Lachowycz \& Jones, 2013), water quality control and storm protection (Windhager et al., 2010), just to name a few.

As one of the matrix elements of urban ecological structure, vegetation may play a major role in promoting ES proficiency through planting design. Although a few examples have explicitly applied the ES approach to urban planting design (Hayek et al., 2010; Hunter, 2011) or to urban forestry (Morani et al., 2011), these are very recent and still emerging. To our knowledge, very few studies address how composition and configuration of urban vegetation might enhance ES proficiency, though this need has been identified (James et al., 2009). It is also important to better understand the relationships between ES and socioeconomic factors, because these can impact urban ecosystems. Acknowledging these topics can provide useful insights to urban planning, planting design and management.

This paper addresses the heterogeneity of urban ES proficiency, and aims to:

- test a conceptual framework relating socioeconomic urban patterns and the shaping of the urban forest structure;

- present a methodology to investigate associations between socioeconomic indicators and structural variables of the urban forest;

- investigate which structural variables of the urban forest, if any, differ along a socioeconomic gradient, to objectively set planning and management goals and contribute to the effective implementation of the ES approach in urban issues.

The city of Porto (located in mainland NW Portugal) is used as a case study, but the methodology can be adapted to other geographical locations and contexts to provide information easily usable by stakeholders and practitioners with responsibilities regarding urban planning and management. 


\section{Methods}

A conceptual framework was developed to underlie the impact of socioeconomic patterns in shaping the urban forest structure across the urban fabric, thus affecting spatially ecosystem services proficiency (Fig. 1).

[Insert figure 1 about here]

This investigation was developed in two phases, with methods and objectives built upon this framework. The first phase aimed to measure the patterns of delivery of some regulating ES provided by trees and shrubs across the city of Porto, using the iTree Eco tool to reveal the heterogeneity of ES proficiency in the urban forest (defined here as the relative ability of trees and shrubs to deliver ES). The second phase consisted of a statistical analysis conducted to investigate potential associations between the urban patterns of ES delivery and socioeconomic indicators, and also to find which structural variables of the urban forest of Porto are more associated with the proficiency of regulating ES. Multimodel inference over one set of generalized linear models was used to analyze associations with socioeconomic indicators, and generalized additive models were developed to investigate relations between structural variables and ES proficiency.

\subsection{Study-area description}

This research was developed within the municipal boundaries of Porto, the second largest Portuguese city.

Porto is located in the northwest of Portugal, facing the Atlantic Ocean at west and Douro River at south and covers $41.42 \mathrm{~km}^{2}$.

[Insert figure 2 about here]

The city is the center of a metropolitan area composed by 17 municipalities adding up to about 1,759,524 inhabitants (INE, 2014) and is currently structured in 7 parishes. Porto has a Mediterranean type climate (Csb climate, according to KöppenGeiger classification) with winter temperatures usually between 5.0 and $16.8^{\circ} \mathrm{C}$, rarely stepping below $0^{\circ} \mathrm{C}$, and summer temperatures typically between 13.8 and $25.0^{\circ} \mathrm{C}$ (but reaching sometimes $36.0^{\circ} \mathrm{C}$ or even more); annual precipitation averages $1254 \mathrm{~mm}$ usually concentrated between October to March (IM, 2011).

During the late $19^{\text {th }}$ century green spaces totalized about $75 \%$ of the city. However, after a century of intense urbanization, in 2000 the green areas amounted to less than $30 \%$ of the city and were characterized by high levels of fragmentation and discontinuity (Madureira et al., 2011).

\subsection{Ecosystem services estimation, sampling design and field protocol}

i-Tree Eco was used to characterize Porto's urban forest structure and to estimate carbon sequestration, pollution removal (of $\mathrm{CO}, \mathrm{NO}_{2}, \mathrm{O}_{3}, \mathrm{PM}_{10}, \mathrm{PM}_{2.5}$ and $\mathrm{SO}_{2}$ ), avoided runoff, energy effects in residential buildings and emission of biogenic volatile organic compounds (BVOCs) by trees and shrubs. i-Tree (www.itreetools.org) is a peer-reviewed software suite developed by the USDA Forest Service and cooperators to analyze the urban forest and the benefits it provides to communities. iTree Eco was originated from the Urban Forest Effects Model UFORE, and requires field data from complete inventories or sample plots, hourly pollution and meteorological information to produce outputs. It provides an extensive characterization 
of the whole urban forest using a bottom-up approach, as described in Nowak et al. (2008a) along with methods to estimate its structure and benefits.

Following guidelines for plot number and size determination (Nowak et al., $2008 \mathrm{~b}$ ), a set of 255 plots with $404.7 \mathrm{~m}^{2}$ each (radius $=11.35 \mathrm{~m}$ ) was set up to obtain field data for the city of Porto (Fig. 2).

A pre-stratification scheme was delimited to assign these plots, with the purpose of obtaining more data to investigate potential differences and causes behind ecosystem services proficiency in green areas among the parish strata. A limit of 10 strata was set to avoid analysis issues during i-Tree Eco data processing, and to ensure that each stratum analyzed contained at least 20 plots. More strata would oblige to allocate more time and resources to collect data, which was not feasible for this research. The prestratification consisted in grouping the 7 parishes of Porto into 5 groups of similar socioeconomic and urban characteristics, obtained using variables derived from the 2011 Census database (INE, 2011), a preliminary analysis of other urban and socioeconomic available data and the author's knowledge of the study area. Each of the 5 groups was then subdivided into a GREEN layer, adapted from a survey from Farinha-Marques (2011), and a GREY layer. GREEN refers to the main green structure of the city, and includes diverse areas such as public and private parks and gardens, green spaces from allotments and urbanizations, tree lined streets and motorway's green strips, wasteland, vacant lots and agricultural areas. GREY refers to the remaining area, consisting of mainly impermeable and densely built areas punctuated by very small green patches and isolated trees. This pre-stratification scheme resulted in 10 strata, which are mapped in Fig. 2. The 255 plots were assigned to the area of each of the five parish groups, totaling $70 \%$ in the green strata and $30 \%$ in the grey strata, to ensure that the biggest effort in field data collection was targeting green areas (generally with higher amount and diversity in terms of vegetation composition and structure).

Field data were collected for 863 trees and shrub cover during the leaf-on season, between mid-May and mid-September 2014. According to the i-Tree Eco field guidelines, vegetation was recorded as tree when the diameter of trunk or bole at breast height (DBH) is greater than or equal to $2.54 \mathrm{~cm}$.

A total of 19 plots was considered inaccessible due to lack of access authorization, security constraints or high density of wild vegetation in abandoned areas. In this last case, field teams could not access the interior of green masses to collect data. To address the lack of data for dense vegetation areas, these were removed from the analysis of Porto. The area of dense vegetation in Porto was calculated using photo-interpretation of 1,500 random points within the city limits using i-Tree Canopy. Inaccessible areas due to high density of vegetation totaled about $1.2 \%$ of the total city area.

Local hourly pollution and weather data were input into the i-Tree Eco model. Hourly air concentrations for $\mathrm{NO}_{2}, \mathrm{SO}_{2}, \mathrm{CO}, \mathrm{O}_{3}, \mathrm{PM}_{10}$ and $\mathrm{PM}_{2.5}$ for 2010 and 2011 were retrieved from the national online database QualAR provided by the Environment Portuguese Agency, for the station of Sobreiras - Lordelo do Ouro, which is the background station collecting data for Porto (APA, n.d.). Hourly weather data for Porto (2010 and 2011) was retrieved from the National Climatic Data Center (www.ncdc.noaa.gov) except precipitation, which was collected in a weather station placed on the roof of the Faculty of Sciences of the University of Porto building ( $41^{\circ} 11^{\prime} \mathrm{N}, 8^{\circ} 39^{\prime} \mathrm{W}$; height: $\left.20 \mathrm{~m}\right)$.

The impact of trees on energy use for residential buildings is estimated in i-Tree Eco using U.S. parameters. For this reason, the energy component of i-Tree Eco was adapted to local parameters for Porto, by adjusting values for frost free length, home 
vintage percentages, primary energy use per type of fuel in residential buildings, energy use in residential buildings for heating, and emission factors for electricity, natural gas and liquefied petroleum gas. The US climate region equivalent chosen for Porto was California Coast.

As i-Tree Eco provides a more exhaustive characterization of tree variables compared to shrubs, only tree data was used in the statistical analysis for this investigation. However, ES estimates presented in the results section also include the contribution of shrubs.

\subsection{Modelling the association of structural variables of the urban forest and socioeconomic indicators}

Socioeconomic variables used for this analysis were selected from the 2011 national census database, after determining which ones accounted for potentially significant differences between parish strata. To assess relationships between structural and socioeconomic variables (dependent and independent variables, respectively) at parish strata level, Spearman correlation coefficients were calculated between the best available socioeconomic variables, and four of them (the least correlated) were selected to represent four different dimensions of socioeconomic patterns: i) Population with college degree; ii) Population age; iii) Time of construction of buildings; and, iv) Building owners vs. tenant percentages (Table 1).

[Insert Table 1 about here]

The structural variables selected were: $\mathrm{DBH}$; tree density; total tree leaf area (TLA), total tree leaf biomass (TLB), tree species density, Simpson's index and tree condition (7 classes ranging from Dead to Excellent). As DBH and tree condition are categorical variables with many classes, only the class having greater Spearman correlation with socioeconomic variables was used to represent each of these two variables. Simpson's index is an indicator of species dominance. i-Tree Eco calculates Simpson's inverse index, which is not a normalized value, and therefore cannot be used to compare different strata. For this research, the complement of Simpson's index was used, corresponding to the probability that any two individuals drawn at random from a finite community belong to different species. Thus, greater values correspond to higher diversity (Magurran, 2004).

Generalized linear models (GLM) were developed to relate each structural variable with the set of socioeconomic variables. GLM are an extension of linear models which allow for non-linearity and non-constant variance structures in data, and thus provide more flexibility to analyse ecological relationships (Guisan et al., 2002).

Each of the five parish strata was disaggregated into their respective GREEN and GREY substrata to increase the number of case units to ten. For each structural variable, four univariate models for each socioeconomic variable were developed; a second set of four models per structural variable was also considered, including the interaction between socioeconomic variables and the type of substrata (GREEN or GREY) thus allowing to separate the effects of socioeconomic conditions for each substratum.

\subsection{Modelling the association of the urban forest structure and ES proficiency}

The second goal of the statistical analysis was to find which structural variables of the urban forest of Porto are associated with the proficiency of ES. For this purpose, 
a set of Generalized Additive Models (GAM) was built. Several ES were considered the response and the structural variables were the explanatory variables. GAM are datadriven rather than model-driven, which means that the fitted values do not come from a model previously assumed (Yee \& Mitchell, 1991). They are more suitable for data exploration and dealing with highly non-linear relationships between the response and explanatory variables (Guisan et al., 2002). Each model related one single response variable (ES) to one explanatory (structural variable), and no interaction effects were considered. Case units corresponded to single tree species in a given GREEN or GREY strata per parish level, totalizing 264 cases. Tree species was a categorical variable with 148 levels in this case. To facilitate modelling, it was converted to a quantitative variable using a "shading factor" as proxy. This factor is used in i-Tree Eco to adjust calculations taking into account the fact that some species have denser canopies than others, which translates into more or less TLA / TLB.

ES considered included stored $\mathrm{C}$ and net sequestered $\mathrm{C}$ per year. Pollution removal and avoided runoff were also considered, using TLA as a proxy because these ES are estimated in i-Tree Eco through a direct relationship with this variable (Hirabayashi et al., 2011). The selected structural variables were: DBH, tree density, tree condition, shading factor and TLB; TLB was not used as an explanatory for TLA because of the high autocorrelation between these variables.

\subsection{Model selection and performance evaluation}

The strength of the association between socioeconomic patterns and the urban forest structure, and between the latter and ES proficiency, was assessed in a trifold process. First, GLM and GAM models were compared and ranked using a Multimodel Inference (MMI) framework based on Akaike Information Criterion with a correction for small sample sizes (AICc) (Burnham et al., 2011). AICc provides a measure that allows comparison of different models, inference about how confident we can be that a given model is the best approximation to reality, and accounting for model selection uncertainty (Symonds and Moussalli, 2011). MMI together with AICc allowed to calculate the $\triangle \mathrm{AICc}$ measure which consists in the difference in AICc values between the best model and each single model. From this, a $\Delta \mathrm{AICc}<2$ suggests substantial evidence for the model, values between 2 and 4 indicate some support, while $\triangle \mathrm{AICc}$ values between 4 and 7 indicate that the model has considerably less support and a $\triangle \mathrm{AICc}>10$ indicates that the model is very unlikely (adapted from Burnham \& Anderson 2002). It is also possible to calculate Akaike weights $\left(\mathrm{w}_{\mathrm{i}}\right)$ which provide an indication of the probability that a given model is the best among the entire set of candidate models which can be translated into a measure of model uncertainty.

This statistical methodology relies on an Information-Theoretic (I-T) approach, which is intrinsically different from methods based on significance testing and model selection based on stepwise or stepdown techniques and presents several advantages for analysing complex ecological processes (see Burnham et al., 2011 and Garamszegi, 2011).

Secondly, the adjusted R-squared was used to assess the explained variance of each model. Lastly, a Null Model $\left(\mathbf{M}_{0}\right)$ in which the structural variable under study was always equal to 1was included in the candidate set and compared with the remaining models. The purpose was to test if a nonsense model could provide more incremental explanatory power than GAM or GLM models.

In each of the three steps described above the strength of the associations under study was independently verified, providing additional evidence for inference. 

2014).

All statistical analyses were conducted in R v.3.1.0 (R Development Core Team,

\section{Results}

\subsection{Global results at city level}

Porto was found to have a considerably low tree cover (10.6\%) and tree density $\left(68\right.$ trees $^{-1}$ ) comparably to most cities reported in Table 2 . About $57 \%$ of all trees had DBH less than $15.2 \mathrm{~cm}$, and about $19 \%$ were between $15.3 \mathrm{~cm}$ and $25.4 \mathrm{~cm}$.

[Insert Table 2 about here]

Only 13 sampled specimens were considered to have impact in energy efficiency of residential dwellings, meaning they were at least $5.5 \mathrm{~m}$ height and closer than $18.28 \mathrm{~m}$ to construction (adapted from McPherson \& Simpson, 1999). This small sample size limited the estimation of energy use impact at city level and comparison between groups of parishes, but revealed that not many trees in Porto are in energy-affecting positions around buildings. Still, the estimated overall impact in the city based on this small sample was an increase in energy use and costs due to tree positions around residential buildings

Quercus robur was the most common tree species (5.3\% of all estimated trees), followed by Populus nigra (4.2\%) and Quercus suber (3.9\%). This is surprising because these species are not typically planted in the city, nor are they abundant in public green areas. They are very common in vacant lots, given their spontaneous nature. However, many times they do not reach mature age because of land use changes.

The species contributing the most to the total TLA of the city were the ornamental trees Platanus x acerifolia (9.7\%) and Acer negundo (6.8\%), even though their total population was not very high (respectively $1.9 \%$ and $2.4 \%$ ). Quercus robur accounted only for $3.5 \%$ of the total TLA.

\subsection{Results at parish level}

The selected socioeconomic indicators revealed that western and southwestern parish groups (" $A$ " and " $D$ ") had a higher proportion of population with college degree and young residents (age $\leq 14$ years); they also corresponded to areas of more recent construction, where more than half of the dwellings were owned by their occupants. The eastern parish (" $B$ "), on the other side, had the lowest proportion of residents with college degree and of dwellings owned by their occupants; it also had a low rate of recent construction, even though this area of the city does not lack space availability, as is the case in the dense city center (" $C$ "). These results suggest that " $A$ " and " $D$ " are wealthier parish groups, and " $\mathrm{B}$ " is the most deprived one; the remaining two parish groups (" $C$ " and " $E$ ") had intermediate wealth conditions (Table 1).

In terms of urban forest structure, emphasis was placed in the comparison of the

five GREEN substrata results because these were obtained from much more field information, collected mostly in green area, which was considered to yield the highest amount of regulating ES provided by vegetation (Table 3).

[Insert Table 3 about here]

The wealthy parishes revealed much better results for tree density than the rest of the groups (Fig. 3).

[Insert Fig. 3 about here] 
Stratum " $B$ " stood out as the parish with fewer trees. However, in most structural indicators (tree species density, TLA, TLB and DBH composition) one of the wealthy parish groups (" $A$ ") did not perform as expected, showing results sometimes below both intermediate parish groups (Table 3 and Fig. 4).

[Insert Fig. 4 about here]

In the case of DBH composition, it was expected that parish groups with higher proportions of trees with low diameters (in classes 0-12.7 and 12.8-25.4 cm) would have lower TLA and TLB per tree. Stratum " $B$ " had the lowest diversity of species, composed mainly of autochthonous species and others with agricultural value, and the lowest Simpson's index value, revealing higher dominance effect of some species than in other strata. On the opposite side, the wealthier parishes had higher prevalence of ornamental species typical of gardens and parks. In the intermediate parish groups, the most striking result was the clear dominance of Acacia melanoxylon, listed as an invasive species by the Portuguese legislation. Strata "A" and "E" had the highest values for Simpson index, reflecting less dominance of species. The most deprived parish consistently revealed poor results in structural variables when compared with the remaining parishes, and the same overall pattern of results was maintained when analyzing ES results. For climate regulation (considering stored C, net sequestered C and avoided runoff) and air purification through pollution removal, the wealthy parish group " $D$ " always presented the highest results, while " $B$ " always showed the worst performance (Table 3, Figures 5 and 6).

[Insert Fig. 5 and Fig. 6 about here]

The other 3 parish groups had similar performances, though the two intermediate-wealthy parish groups had better results than the wealthy parish group " $A$ ". In any case, stratum " $C$ " always presented better results than " $A$ " and " $E$ ".

Parish groups with less TLB had lower BVOC emission density and thus were less affected by the potentially negative impact of BVOC emissions (Fig. 7).

[Insert Fig. 7 about here]

However, it should be noted that many of the dominant tree species found in Porto are high BVOC-emitters, such as Quercus robur (Donovan et al., 2005), Platanus $x$ acerifolia (Aydin et al., 2014), Liquidambar styraciflua (Benjamin et al., 1996) and Populus nigra (Owen et al., 2001).

\subsection{Relation between the urban forest structure and socioeconomic indicators}

Model selection based on AICc and GLM revealed a strong support for associations between socioeconomic and all structural variables considered, as shown by the $\triangle \mathrm{AICc}$ ranking presented in Table 4 (models with the strongest support had the lowest $\triangle \mathrm{AICc}$ value of 0.00 , and generally higher adjusted R-squared values).

[Insert Table 4 about here]

The performance of the Null Model $\left(\mathrm{M}_{0)}\right.$ further reinforced this observation, since it was consistently ranked below models including socioeconomic variables. Some of the structural variables revealed stronger associations for models considering the interaction between socioeconomic variables and the type of substrata (GREEN or GREY). This was the case for tree density, for which the best explanatory model was $\mathrm{M}_{\mathrm{B} 2 \mathrm{i}}$, which considered the interaction between "Population with College Degree" and "Type of substratum" as explanatory. The same applied to TLA (best model: $\mathrm{M}_{\mathrm{D} 2 \mathrm{i}}$ ), TLB (best model: $\mathrm{M}_{\mathrm{E} 2 \mathrm{i}}$ ) and tree species per hectare (best model: $\mathrm{M}_{\mathrm{F2} 2}$ ), all revealing that "Population with College Degree" and "Type of substratum" yielded the maximum 
explanatory power for the response considered. The best model for Simpson's index $\left(\mathrm{M}_{\mathrm{G} 4 \mathrm{i}}\right)$ was sensitive to the interaction between the type of Subtrata, and the variable "Built until 1945", considered in the socioeconomic dimension of "Time of construction of buildings" referred in section 2.3. DBH and tree condition were less benefited in terms of model performance by the inclusion of the interaction term, as revealed by the $\triangle \mathrm{AICc}$ ranking. For DBH, the best model was $\mathrm{M}_{\mathrm{A} 1}$, with only "Owner or co-owner" as explanatory variable (which was considered in the socioeconomic dimension of "Building owners vs. tenant percentages"), followed at a short distance by "Built until 1945 ". Tree condition revealed a stronger association with "Building time between 1981 and 2011".

\subsection{Relation between structural variables of the urban forest and ES proficiency}

Tree DBH was the structural variable with the highest support for explaining climate regulation through Stored $\mathrm{C}\left(\triangle \mathrm{AICc}=0.00, \mathrm{R}^{2}\right.$ adjusted $\left.=0.72\right)$. However, for $\mathrm{C}$ Net Sequestration the TLB variable recorded by far the strongest predictive support $\left(\triangle \mathrm{AICc}=0.00, \mathrm{R}^{2}\right.$ adjusted $\left.=0.46\right)$. TLA was used as a proxy to assess both air purification through removal of air pollutants and also climate regulation through avoided water runoff. In this case again, Tree DBH was the variable with the strongest explanatory power $\left(\triangle \mathrm{AICc}=0.00, \mathrm{R}^{2}\right.$ adjusted $\left.=0.51\right)$. TLA was used as a response variable only, and TLB as explanatory just for the other response variables. Otherwise, it is expected that TLA would have similar results to TLB in terms of impact in ES proficiency, because these variables were highly correlated. For all the four ES analyzed through model selection based on AICc using GAM, the Null model was the one with higher values of $\triangle \mathrm{AIC}$ (between 157.12 and 325.87), thus revealing no support among all the response variables in the candidate set (Table 5).

[Insert Table 5 about here]

Results suggest that tree DBH and TLB are of major importance to the proficiency of ES provided by urban trees in Porto, and that tree density has a moderate effect in $\mathrm{C}$ Net Sequestration ( $\triangle \mathrm{AICc}>10$ but reasonable adjusted $\mathrm{R}$-squared value), to low impact in the other response variables analyzed ( $\triangle \mathrm{AICc}>100$ and low adjusted Rsquared value). Shading Factor (used as a proxy to analyze species effects) emerged as having very low impact in proficiency of regulating ES in Porto, thus suggesting that tree $\mathrm{DBH}$ and leaf biomass have a much more important role than the type of species.

\section{Discussion}

Overall, results from GLM and MMI analyses revealed a strong association between spatial patterns of wealth and structural variables of Porto's urban forest, highlighted by better indicator values in the western and southwestern parish groups, and the poorest values in the less wealthy stratum " $B$ ". Some structural variables emerged as being also dependent of the type of substratum considered for data collection. This was the case for tree density, TLA, TLB and tree species per hectare, which were naturally much higher in GREEN substrata, where the highest proportion of trees was expected. It was also the case for Simpson's index, because GREEN substrata had generally more diversity than GREY substrata. DBH and tree condition are less dependent of tree quantity, and thus were not very affected by substratum type. GAM analysis revealed that the variables with highest impact in the proficiency of the four regulation ES analyzed for Porto were tree DBH and tree biomass, surpassing by 
far tree density and the effect of the type of species (in terms of compactness of canopy). As in Porto about two quarters of the trees were found to have a low DBH (below $25.4 \mathrm{~cm}$ ), these results suggest that it is very important for ES proficiency to allow trees to develop to full size. In addition, severely pruned trees are common in this city and TLA/TLB were low in many sampled specimens with high DBH, suggesting that tree density or high DBH only do not compensate low TLB for C net sequestration. Inadequate species selection and inappropriate planting location were probably the most relevant factors that prevented trees to grow to full extent. This had a clear impact in ES proficiency, as shown with energy efficiency results.

The civil parish of "Campanhã" (stratum "B") is usually considered by Porto's inhabitants and stakeholders as the greenest of Porto. This is due to its yet rural character, that survived the overwhelming urbanization of the city during the last century (Madureira et al., 2011). However, results from this research showed that " $B$ " had by far the lowest tree density, highest rate of trees with low DBH, higher dominance effect of some species and lower ES proficiency in its green stratum, even though it had the highest proportion of green areas (46.80\%; see Table 3 ).

Interestingly, the green stratum " $A$ " had the second highest tree density and proportion of green areas in parish, but this was not accompanied by results in ES proficiency. The two parish groups with intermediate socioeconomic indicators (strata "C" and "E") had higher densities of stored $\mathrm{C}$, net $\mathrm{C}$ sequestration, pollution removal and avoided runoff, especially " $C$ ". Stratum " $C$ " is historically the oldest area of Porto, and this was reflected by $\mathrm{DBH}$ composition of trees, which showed the lowest proportion of trees with $\mathrm{DBH}<12.7 \mathrm{~cm}$. " $A$ " is much more recent in terms of construction age (table 1), and had the second highest proportion of trees with DBH < $25.4 \mathrm{~cm}$ (about 79\%). These findings suggest that average building age is an important indicator of ES proficiency in Porto. However, stratum " $A$ " had a considerable number of new green areas with very young trees in public spaces that are expected to develop in the coming years, and thus they will probably surpass in ES proficiency the parishes with intermediate or low socioeconomic indicators. It should be noted that possible leakage effects of ES provision among parish groups do not compensate the socioecological inequity evidenced by this research, as benefits such as avoided runoff, microclimate impact and energy efficiency are enjoyed essentially by dwellers in the near surroundings of the green areas providing these ES.

Higher values of Simpson's index in GREEN substrata with greater proportion of recent construction ("A" and "E") also reinforce the influence of average building age in the urban forest. Results suggest that socioeconomic patterns in Porto are associated with species diversity of the urban forest. This is more visible in " $C$ ", where a high prevalence of vacant areas and abandoned houses with private gardens/backyards is contributing to the expansion of the alien invasive Acacia melanoxylon (Table 3). In stratum " $B$ " there was a lower prevalence of this species. However, the existence of many vacant areas is also giving rise to the rapid expansion of Buddleja davidii, an exotic ornamental shrub species very common in private gardens and not yet declared invasive in Portugal by the national legislation, but already listed in Spain. Although invasive species provide regulating ES, their negative impact in local biodiversity is an important trade-off that should also be considered when assessing their role for ES overall proficiency. Both GREEN substrata " $B$ " and " $C$ " recorded the two lowest Simpson index values, which reveals the dominance effect of some species and lower diversity compared with the other parish groups. Tree species density was also considerably lower in " $B$ " than in the rest of the city, thus affecting resilience of the urban forest in this area of the city, by increasing vulnerability to plagues and diseases. 
Results from this investigation are in line with findings of previous research concluding that less wealthy areas are more exposed to ES inequity (Escobedo et al., 2015; Jenerette et al., 2011; Landry and Chakraborty, 2009; Romero et al., 2012). However, there is also evidence of higher ES delivery in lower-income areas, compared to wealthier zones of cities such as Paris (Cohen et al., 2012) and Santiago do Chile (Escobedo and Nowak, 2009). This apparent contradiction might be explained by the impact of local factors such as planning trends (Cohen et al., 2012) or heterogeneity of pollution concentrations due to anthropogenic and biophysical factors, as was found in Santiago do Chile, where Escobedo and Nowak (2009) observed that pollution removal of PM10 was highest in low socioeconomic areas even though these had the lowest vegetative cover. As trees take a long time to grow, shifting socioeconomic patterns can also be reflected by a lag effect between the plantation of trees by a certain socioeconomic group, and fruition of their benefits by a different socioeconomic group.

Our results further indicate that building age is also a powerful variable to explain deviances from a linear relationship between ES proficiency and socioeconomic wealth, confirming previous findings (Grove et al., 2006; Hope et al., 2003). This means that the maturity of trees and green spaces in older urban areas can have a stronger impact in ES proficiency than higher densities of trees observed in wealthier parts of the city. However, recently constructed areas revealed more diversity in the urban forest, and if trees can fully develop in these areas a more direct association between ES proficiency and socioeconomic patterns is expected.

All these considerations strongly suggest that before setting planning and management goals, it is crucial to understand local patterns of ES, and their relationships with socioeconomic patterns, which can be affected by other variables such as building age. This understanding should be followed by the identification of structural variables of the urban forest that better explain the differences, in order to target these variables through planning and management goals. The conceptual framework adopted in this research (Fig. 1) can guide adaptation of our methodology to other cities, and provide insights for planning and management suitable to site-specific conditions and directly usable by stakeholders.

Some limitations and caveats should be acknowledged. i-Tree Eco uses measured hourly pollutant concentration which is assumed to be consistent throughout the city (i.e., concentration does not vary at the local scale). Also deposition velocities per unit of canopy cover is dependent upon an average leaf area index for the city, thus pollution removal is proportional to leaf area with no differentiation among individual species differences that may affect deposition velocities (Sæbø et al., 2012).

\section{Conclusion}

Planning and management goals for Porto can draw upon this research, such as targeting planting trees in the areas where ES proficiency needs reinforcement to mitigate inequity in ES delivery. Similarly, more attention could be given to the proper establishment of trees to allow for the full development of mature tree canopies and size, since results suggest that higher DBH (and consequently higher TLB in living trees) is a major factor impacting ES proficiency. Also, planting trees near buildings could be focused upon if energy efficiency benefits are to be attained. Porto's urban forest resilience can be improved with diversification of tree species used in new plantations, particularly in the most deprived parish, and better control of invasive vegetation in the city center and "Campanhã" (stratum "B"). BVOC emissions might be mitigated using low-emitting species in new plantations. These findings can contribute 
to sustain the foundation for a municipal strategy for trees, ES proficiency and equity, as well as to change the current national legislative model.

The variation in ES/socioeconomic relationships found among other cities in previous research suggests that site-specific factors have major impact in ES proficiency across the urban fabric. Planning and management goals should evolve from a paradigm more grounded in a set of indicators able to capture the dynamics of local socialecological systems. This can be accomplished by determining local patterns and direction of ES/socioeconomic relationships, followed by identification of structural variables of the urban forest that better explain the differences. The proposed conceptual framework (Fig. 1) and methodology can be used in other cities, and results directly applied by local stakeholders to assess and establish monitoring benchmarks in ES proficiency across the city and to compare before/after scenarios for interventions. Mismatches between the local scale and planning/management goals at larger scales could be better understood and addressed, specifically the social-ecological dynamics that prevent some goals to be attained. Examples include the impact of private owner preferences regarding species and location choice for trees, frequent land use changes that impede trees from achieving larger sizes, proliferation of invasive species in vacant areas, and low ES proficiency even when green area is abundant and tree density is reasonable.

Future research is needed to address proficiency for ES, and contribute to develop a framework where trade-offs between negative impacts (e.g., invasive alien and high BVOC emission impacts) and positive effects of trees are considered to adequately inform the planning and design process.

\section{Acknowledgments}

We are grateful to Nuno Rodrigues, Daniela Cunha, Vasco Silva and Patrícia Monteiro for their assistance in the field work, and to Satoshi Hirabayashi and Daniel E. Crane, of the USDA Forest Service Northern Research Station, and Nuno Formigo, of the Faculty of Sciences of the University of Porto, for clarifications about calculation assumptions behind i-Tree Eco. We also thank the Institute of Earth Sciences (University of Porto) for providing precipitation data to run i-Tree Eco, and to the City Council of Porto for providing useful geographical information and data referring to existing tree surveys. This research was partially funded by the Portuguese Agency for Science and Technology (FCT) through PhD grant of M. Graça SFRH/BD/91028/2012 and PhD grant of J. Gonçalves SFRH/BD/90112/2012, both financed by national funds of the Ministry for Science and Education and by the European Social Fund through POPH QREN - Tipology 4.1 - Advanced Training.

\section{References}

Ahern, J., 2013, Urban landscape sustainability and resilience: The promise and challenges of integrating ecology with urban planning and design, Landscape Ecology 28(6): 1203-1212.

Ahern, J., Cilliers, S., Niemelä, J., 2014, The concept of ecosystem services in adaptive urban planning and design: A framework for supporting innovation, Landscape and Urban Planning 125(0):254-259.

Andersson, E., Barthel, S., Ahrne, K., 2007, Measuring social-ecological dynamics behind the generation of ecosystem services, Ecological Applications 17(5):1267-1278. 
APA, n.d., Agência Portuguesa do Ambiente, QualAR - Base de Dados Online sobre a Qualidade do Ar (Online Database for Air Quality). Retrieved November 4, 2014 from http://qualar.apambiente.pt/.

Aydin, Y. M., Yaman, B., Koca, H., Dasdemir, O., Kara, M., Altiok, H., Dumanoglu, Y., Bayram, A., Tolunay, D., Odabasi, M., Elbir, T., 2014, Biogenic volatile organic compound (BVOC) emissions from forested areas in Turkey: Determination of specific emission rates for thirty-one tree species, Science of The Total Environment 490:239-253.

Baró, F., Haase, D., Gómez-Baggethun, E., Frantzeskaki, N., 2015, Mismatches between ecosystem services supply and demand in urban areas: A quantitative assessment in five European cities, Ecological Indicators 55(0):146-158.

Beckett, K. P., Freer-Smith, P. H., Taylor, G., 2000, The capture of particulate pollution by trees at five contrasting urban sites, Arboricultural Journal 24(2-3):209.

Benjamin, M. T., Sudol, M., Bloch, L., Winer, A. M., 1996, Low-emitting urban forests: A taxonomic methodology for assigning isoprene and monoterpene emission rates, Atmospheric Environment 30(9):1437-1452.

Berkes, F., Colding, J., Folke,C. (Eds.), 2003, Navigating Social-Ecological Systems: Building Resilience for Complexity and Change, Cambridge University Press, pp. 416.

Bolund, P., Hunhammar, S., 1999, Ecosystem services in urban areas, Ecological Economics 29(2):293-301.

Burnham, K. P., Anderson, D. R., 2002, Model selection and multimodel inference: A practical information-theoretic approach. 2nd edition. Springer-Verlag, New York.

Burnham, K., Anderson, D., Huyvaert, K., 2011, AIC model selection and multimodel inference in behavioral ecology: some background, observations, and comparisons, Behavioral Ecology and Sociobiology 65(1):23-35.

Cadotte, M. W., Carscadden, K., Mirotchnick, N., 2011, Beyond species: functional diversity and the maintenance of ecological processes and services, Journal of Applied Ecology 48(5):1079-1087.

CJC, n.d., City of Jersey City. Retrieved January 11, 2016 from http://www.jerseycitynj.gov/about.aspx?id=1208\&terms=area

Cohen, M., Baudoin, R., Palibrk, M., Persyn, N., Rhein, C., 2012, Urban biodiversity and social inequalities in built-up cities: New evidences, next questions. The example of Paris, France, Landscape and Urban Planning 106(3):277-287.

Colding, J., 2011, The Role of Ecosystem Services in Contemporary Urban Planning, in: Urban Ecology: Patterns, processes and applications (J. Niemelä, ed.), Oxford University Press, Oxford, pp. 228-237.

DCPNY, n.d., Department of City Planning of New York. Retrieved January 8, 2016 from http://www.nyc.gov/html/dcp/pdf/neigh_info/profile/nyc_profile.pdf.

Díaz, S., Cabido, M., 2001, Vive la différence: plant functional diversity matters to ecosystem processes, Trends in Ecology \& Evolution 16(11):646-655.

Donovan, R. G., Stewart, H. E., Owen, S. M., Mackenzie, A. R., Hewitt, C. N., 2005, Development and application of an urban tree air quality score for photochemical pollution episodes using the Birmingham, United Kingdom, area as a case study, Environmental Science \& Technology 39(17):6730-6738.

Escobedo, F. J., Clerici, N., Staudhammer, C. L., Corzo, G. T., 2015, Socio-ecological dynamics and inequality in Bogotá, Colombia's public urban forests and their ecosystem services, Urban Forestry \& Urban Greening 14(4):1040-1053. 
Escobedo, F. J., Nowak, D. J., 2009, Spatial heterogeneity and air pollution removal by an urban forest, Landscape and Urban Planning 90(3-4):102-110.

Escobedo, F. J., Nowak, D. J., Wagner, J. E., De la Maza, C. L., Rodríguez, M., Crane, D. E., Hernández, J., 2006, The socioeconomics and management of Santiago de Chile's public urban forests, Urban Forestry and Urban Greening 4(3-4):105114.

Farinha-Marques, F., Fernandes, C., Lameiras, J. M., Silva, S., Leal, I., Guilherme,F., 2011, Morfologia e Biodiversidade nos Espaços Verdes da Cidade do Porto. Livro 1 - Seleção das áreas de estudo (Morphology \& Biodiversity in the Urban Green Spaces of the City of Porto. Book 1 - Selection of the Study Areas), CIBIO

- Research Centre in Biodiversity and Genetic Resources.

Fisher, B., Turner, R. K., Morling, P., 2009, Defining and classifying ecosystem services for decision making, Ecological Economics 68(3):643-653.

Freer-Smith, P. H., Beckett, K. P., Taylor, G., 2005, Deposition velocities to Sorbus aria, Acer campestre, Populus deltoides X trichocarpa 'Beaupre', Pinus nigra and $\mathrm{X}$ Cupressocyparis leylandii for coarse, fine and ultra-fine particles in the urban environment, Environmental Pollution 133(1):157-167.

Garamszegi, L. Z., 2011, Information-theoretic approaches to statistical analysis in behavioural ecology: An introduction, Behavioral Ecology and Sociobiology 65(1):1-11.

Gomez-Baggethun, E., Barton, D. N., 2013, Classifying and valuing ecosystem services for urban planning, Ecological Economics 86:235-245.

Grove, J. M., Troy, A. R., O'Neil-Dunne, J. P. M., Burch, W. R., Cadenasso, M. L., Pickett, S. T. A., 2006, Characterization of households and its implications for the vegetation of urban ecosystems, Ecosystems 9(4):578-597.

Guisan, A., Edwards Jr, T. C., Hastie, T., 2002, Generalized linear and generalized additive models in studies of species distributions: setting the scene, Ecological Modelling 157(2-3):89-100.

Haase, D., Larondelle, N., Andersson, E., Artmann, M., Borgstrom, S., Breuste, J., Gomez-Baggethun, E., Gren, A., Hamstead, Z., Hansen, R., Kabisch, N., Kremer, P., Langemeyer, J., Rall, E. L., McPhearson, T., Pauleit, S., Qureshi, S., Schwarz, N., Voigt, A., Wurster, D., Elmqvist, T., 2014, A Quantitative Review of Urban Ecosystem Service Assessments: Concepts, Models, and Implementation, Ambio (4):413.

Hayek, U., Neuenschwander, N., Halatsch, J., Grêt-Regamey, A., 2010, Procedural Modeling of Urban Green Space Pattern Designs Taking into Account Ecological Parameters, in: Future cities: 28th eCAADe Conference Proceedings, ETH Zurich, Zurich, Switzerland.

Hermann, A., Schleifer, S., Wrbka, T., 2011, The Concept of Ecosystem Services Regarding Landscape Research: A Review, Living Reviews in Landscape Research 5:1-37.

Hirabayashi, S., Kroll, C. N., Nowak, D. J., 2011, Component-based development and sensitivity analyses of an air pollutant dry deposition model, Environmental Modelling \& Software 26(6):804-816.

Hölzinger, O., Horst, D. v. d., Sadler, J., 2014, City-wide Ecosystem AssessmentsLessons from Birmingham, Ecosystem Services 9:98-105.

Hope, D., Gries, C., Zhu, W. X., Fagan, W. F., Redman, C. L., Grimm, N. B., Nelson, A. L., Martin, C., Kinzig, A., 2003, Socioeconomics drive urban plant diversity, Proceedings of the National Academy of Sciences of the United States of America 100(15):8788-8792. 
Hunter, M., 2011, Using Ecological Theory to Guide Urban Planting Design: An adaptation strategy for climate change, Landscape Journal 30(2):174-193.

IM, 2011, in: Iberian Climate Atlas - Air Temperature and Precipitation (1971-2000), Instituto de Meteorologia, pp. 80.

INE, 2011, Censos 2011 (Census 2011). Instituto Nacional de Estatística. Retrieved April 9, 2014 from http://censos.ine.pt/xportal/xmain?xpid=CENSOS\&xpgid=ine_censos_indicador es.

INE, 2014, in: Tipologia Socioeconómica das Áreas Metropolitanas de Lisboa e Porto 2011 (Socioeconomic Typology of the Metropolitan Areas of Lisbon and Porto 2011). Lisboa, Instituto Nacional de Estatística, I.P. (Statistics Portugal). Retrieved January 7, 2016 from https://www.ine.pt/xportal/xmain?xpid=INE\&xpgid=ine_publicacoes.

James, P., Tzoulas, K., Adams, M. D., Barber, A., Box, J., Breuste, J., Elmqvist, T., Frith, M., Gordon, C., Greening, K. L., Handley, J., Haworth, S., Kazmierczak, A. E., Johnston, M., Korpela, K., Moretti, M., Niemela, J., Pauleit, S., Roe, M. H., Sadler, J. P., Thompson, C. W., 2009, Towards an integrated understanding of green space in the European built environment, Urban Forestry \& Urban Greening 8(2):65-75.

Jenerette, G. D., Harlan, S. L., Stefanov, W. L., Martin, C. A., 2011, Ecosystem services and urban heat riskscape moderation: water, green spaces, and social inequality in Phoenix, USA, Ecological Applications 21(7):2637-2651.

Kabisch, N., Haase, D., 2014, Green justice or just green? Provision of urban green spaces in Berlin, Germany, Landscape and Urban Planning 122(0):129-139.

Kuo, F. E., 2001, Coping with poverty. Impacts of environment and attention in the inner city, Environment and Behavior 33(1):5-34.

Lachowycz, K., Jones, A. P., 2013, Towards a better understanding of the relationship between greenspace and health: Development of a theoretical framework, Landscape and Urban Planning 118(0):62-69.

Landry, S. M., Chakraborty, J., 2009, Street trees and equity: evaluating the spatial distribution of an urban amenity, Environment and Planning A 41(11):26512670.

Madureira, H., Andresen, T., Monteiro, A., 2011, Green structure and planning evolution in Porto, Urban Forestry \& Urban Greening 10(2):141-149.

Magurran, A. E., 2004, Measuring Biological Diversity, Blackwell Science Ltd.

McPhearson, T., Andersson, E., Elmqvist, T., Frantzeskaki, N., 2015, Resilience of and through urban ecosystem services, Ecosystem Services 12:152-156.

McPherson, E. G., Simpson, J.R., 1999, Carbon dioxide reduction through urban forestry: Guidelines for professional and volunteer tree planters. (General Technical Report PSW-171). Albany, CA, U.S. Department of Agriculture, Forest Service, Pacific Southwest Research Station, pp. 237.

MEA, 2005, Ecosystems and human well-being: synthesis, in: Millenium Ecossystem Assessment (MEA). Retrieved July 8, 2014 from http://www.millenniumassessment.org/en/Synthesis.html, pp. 155.

Morani, A., Nowak, D. J., Hirabayashi, S., Calfapietra, C., 2011, How to select the best tree planting locations to enhance air pollution removal in the MillionTreesNYC initiative, Environmental Pollution 159(5):1040-1047.

Nowak, D. J., Crane, D. E., Stevens, J. C., Hoehn, R. E., Walton, J. T., Bond, J., 2008a, A ground-based method of assessing urban forest structure and ecosystem services, Arboriculture and Urban Forestry 34(6):347-358. 
Nowak, D. J., Hoehn III, R. E., Bodine, A. R., Greenfield, E. J., Ellis, A., Endreny, T.A., Yang, Y., Zhou,T., Henry, R., 2013, Assessing Urban Forest Effects and Values: Toronto's Urban Forest, U.S. Forest Service, Northern Research Station Resource Bulletin NRS-79. Newtown Square, PA. 59 p. Retrieved October 9, 2015 from http://www.nrs.fs.fed.us/pubs/rb/rb_nrs79.pdf.

Nowak, D.J., Hoehn III, R..E., Crane, D.E., Stevens, J.C., Walton, J.T., 2007, Assessing urban forest effects and values: New York City's urban forest. USDA Forest Service, Northern Research Station Resource Bulletin NRS-9. Newtown Square, PA. 24 p.

Nowak, D. J., Stevens, J. C., Crane, D. E., Hoehn, R. E., Walton, J. T., 2008b, Effect of plot and sample size on timing and precision of urban forest assessments, Arboriculture and Urban Forestry 34(6):386-390.

Owen, S. M., Boissard, C., Hewitt, C. N., 2001, Volatile organic compounds (VOCs) emitted from 40 Mediterranean plant species:: VOC speciation and extrapolation to habitat scale, Atmospheric Environment 35(32):5393-5409.

PFR, n.d., in: Parks, Forestry \& Recreation - Urban Forestry; Every Tree Counts - A Portrait of Toronto's Urban Forest. Retrieved October 9, 2015 from https://www.itreetools.org/resources/reports.php.

R Development Core Team, 2014, R: A language and environment for statistical computing, R Foundation for Statistical Computing, Vienna, Austria.

Rogers, K., Jarratt, T., Hansford, D., 2011, Torbay's Urban Forest - Assessing Urban Forest Effects and Values. Exeter, Treeconomics. Retrieved October 9, 2015 from https://www.itreetools.org/resources/reports.php.

Romero, H., Vásquez, A., Fuentes, C., Salgado, M., Schmidt, A., Banzhaf, E., 2012, Assessing urban environmental segregation (UES). The case of Santiago de Chile, Ecological Indicators 23(0):76-87.

Rumble, H., Rogers, K., Doick, K., Albertini, A., Hutchings, T., 2015, Valuing urban trees in Glasgow - Assessing the Ecosystem Services of Glasgow's Urban Forest: A Technical Report. Retrieved October 9, 2015 from http://www.forestry.gov.uk/pdf/FR_Doick_GlasgowItreereportFINAL.pdf/\$FIL E/FR_Doick_GlasgowItreereportFINAL.pdf.

Rumble, H., Rogers, K., Doick, K., Hutchings, T., 2014, Valuing Wrexham's Urban Forest - Assessing the Ecosystem Services of Wrexham's Urban Trees: A Technical Report. Retrieved October 9, 2015 from http://www.forestry.gov.uk/pdf/FR_Doick_Wrexham_iTree_Full_Report_2015. pdf/\$file/FR_Doick_Wrexham_iTree_Full_Report_2015.pdf.

Sæbø, A., Popek, R., Nawrot, B., Hanslin, H. M., Gawronska, H., Gawronski, S. W., 2012, Plant species differences in particulate matter accumulation on leaf surfaces, Science of the Total Environment 427-428:347-354.

Seppelt, R., Dormann, C. F., Eppink, F. V., Lautenbach, S., Schmidt, S., 2011, A quantitative review of ecosystem service studies: approaches, shortcomings and the road ahead, Journal of Applied Ecology 48(3):630-636.

Symonds, M. E., Moussalli, A., 2011, A brief guide to model selection, multimodel inference and model averaging in behavioural ecology using Akaike's information criterion, Behavioral Ecology and Sociobiology 65(1):13-21.

United Nations, 2014, in: World Urbanization Prospects: The 2014 Revision, Highlights (ST/ESA/SER.A/352), available online at http://esa.un.org/unpd/wup/highlights, pp. 32.

Windhager, S., Steiner, F., Simmons, M. T., Heymann, D., 2010, Toward Ecosystem Services as a Basis for Design, Landscape Journal 29(2):107-123. 
Yee, T. W., Mitchell, N. D., 1991, Generalized additive models in plant ecology, Journal of Vegetation Science 2(5):587-602. 


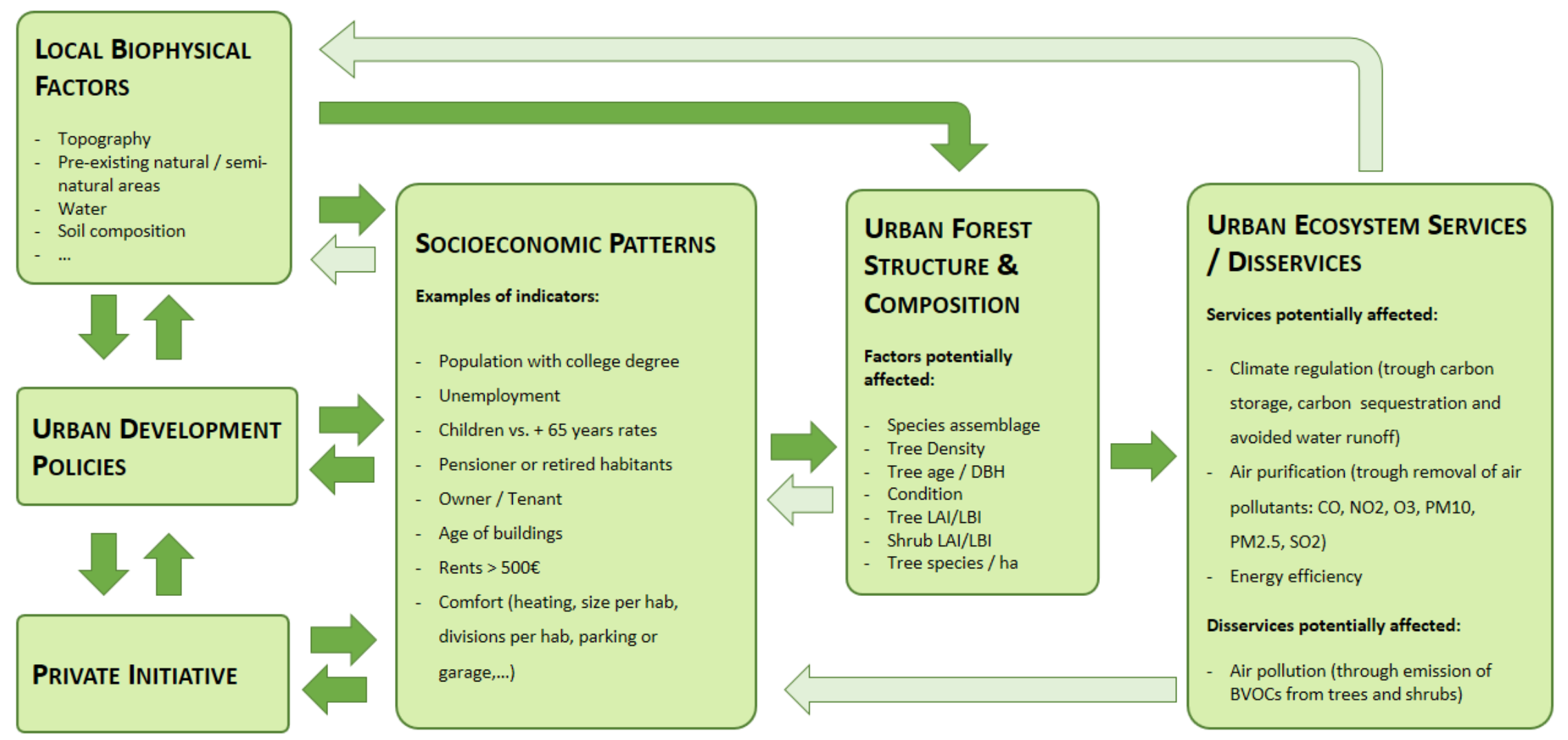

Fig 1: Conceptual framework underlying the impact of socioeconomic patterns in shaping differently the urban forest structure across the urban fabric, thus affecting spatially ecosystem services proficiency. Dark green arrows highlight relationships predominantly direct, and light green stresses connections assumed to be more indirect among components of the framework. 

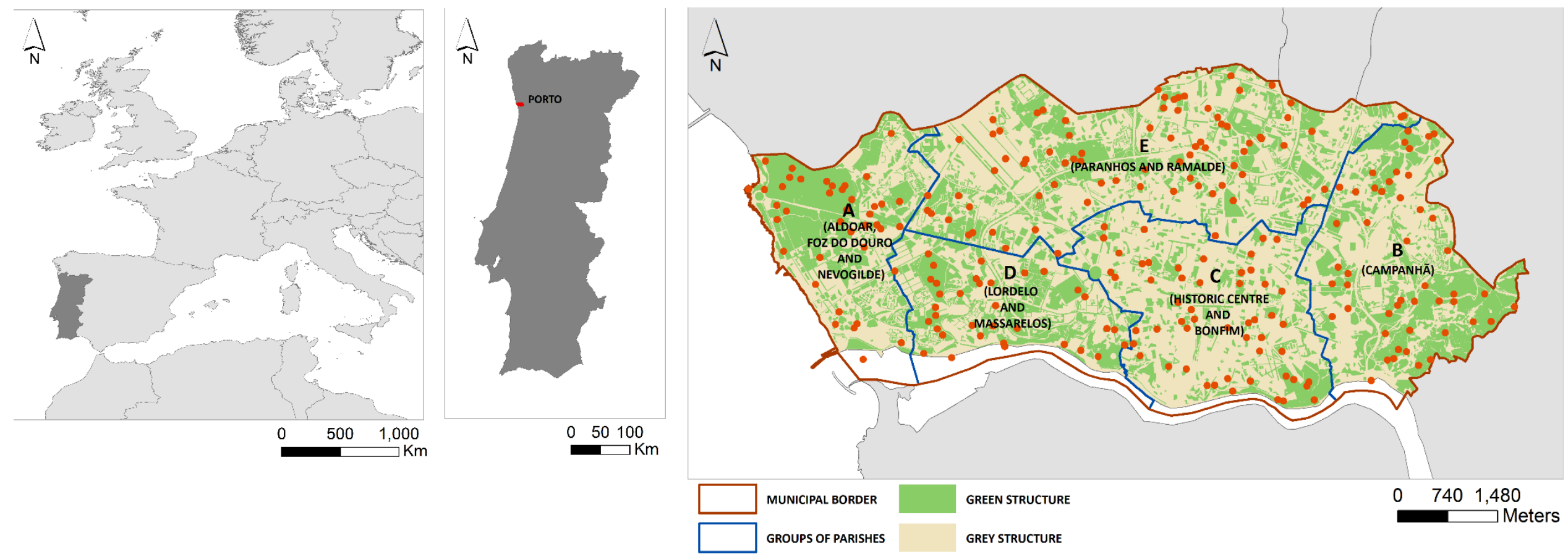

- $\quad$ SAMPLE PLots

Fig 2: Location of the study area (left and center) and pre-stratification scheme used in this investigation for sampling design (right). The green infrastructure was used to subdivide each parish group in two layers: GREEN refers to refers to the main green structure of the city (e.g. parks and gardens, tree lined streets and motorway's green strips, wasteland, agricultural areas, ...); GREY refers to the remaining area (mainly impermeable and densely built areas punctuated by very small green patches and isolated trees). The capital letters A, B, C, D and E are the short names used to refer parish strata in text. 
250

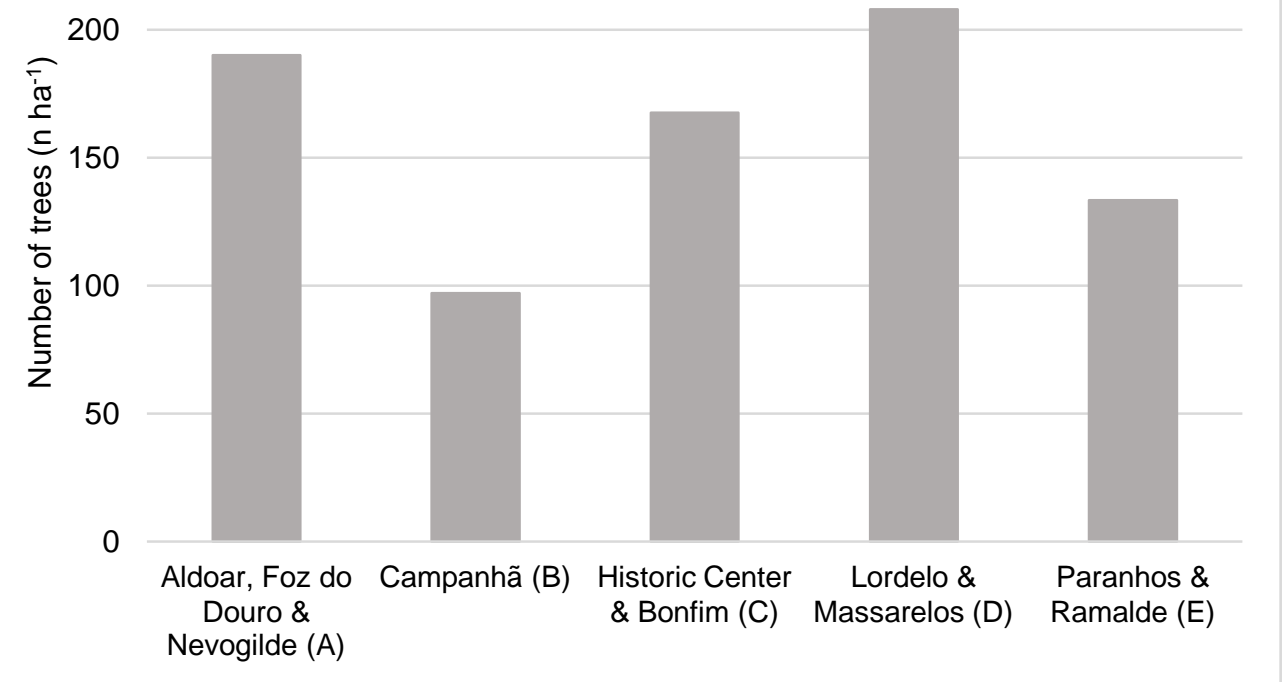

Fig 3: Tree density in GREEN strata, according to parish groups in Porto. 


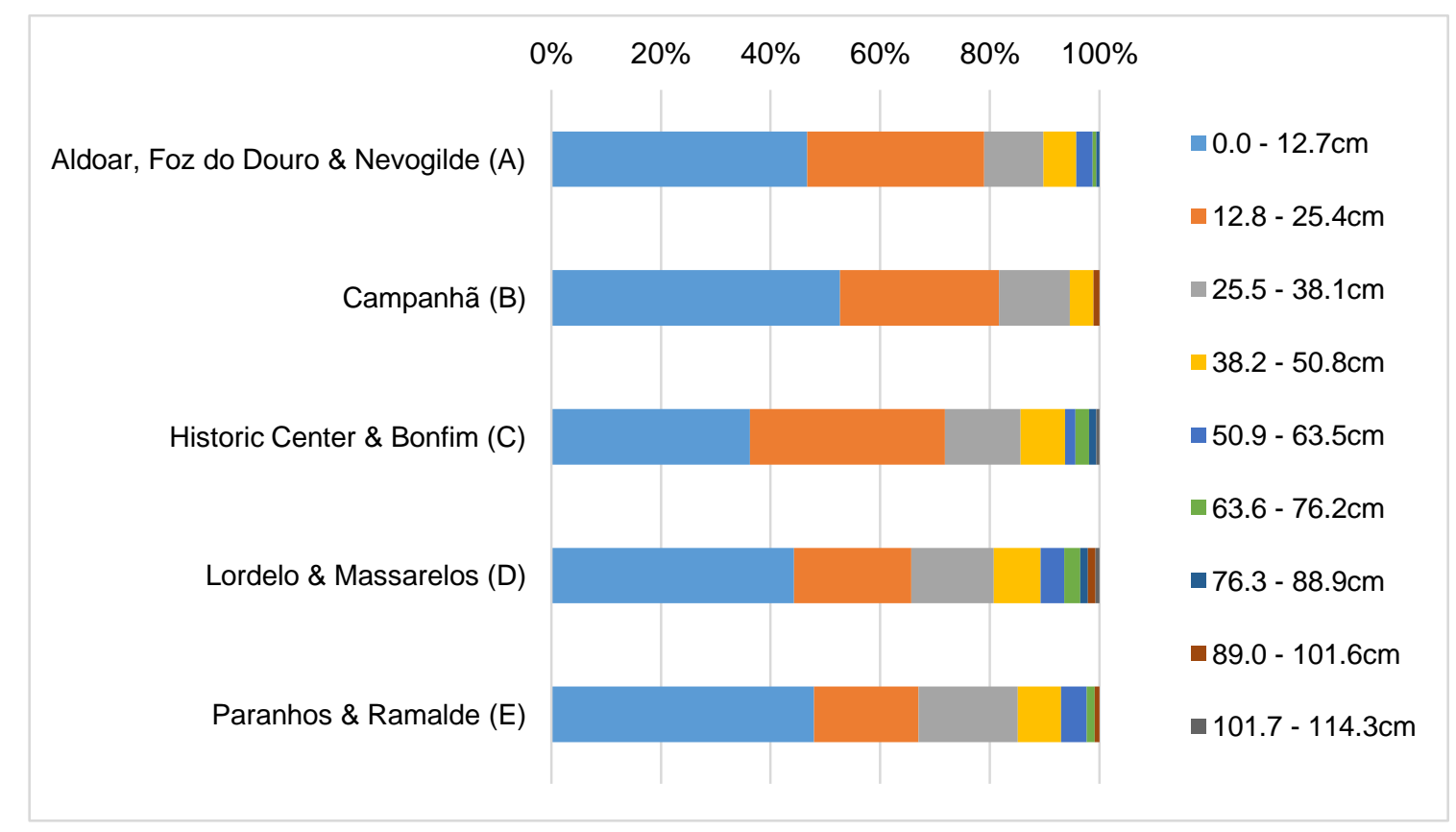

Fig 4: Composition of tree population in GREEN strata according to Diameter at Breast Height (DBH) class, per parish group of Porto. The smallest trees (class $0.0-12.7 \mathrm{~cm}$ ) account for the higher proportion of trees in all parish groups. (For interpretation of the references to color in this artwork, the reader is referred to the web version of the article). 


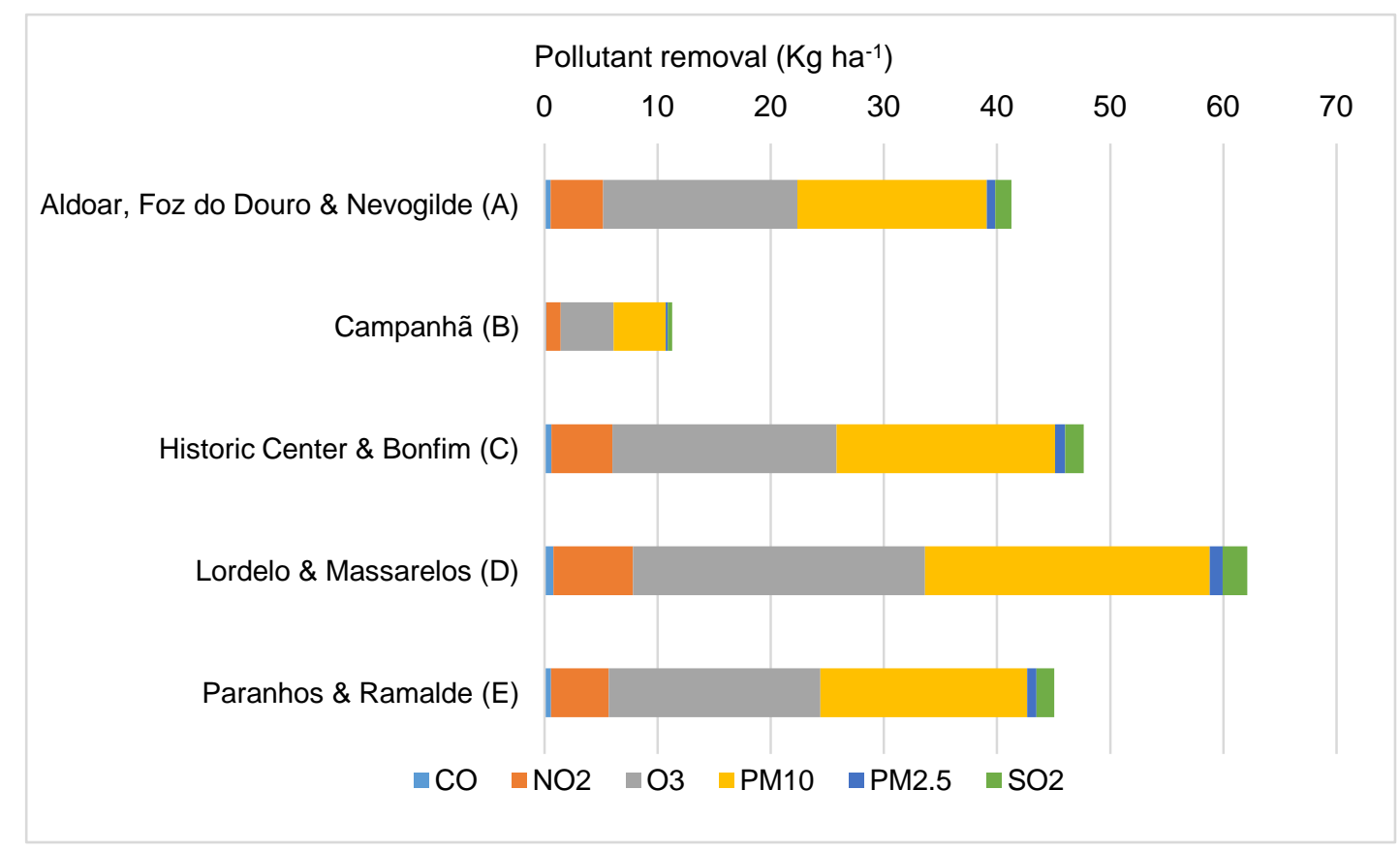

Fig 5: Mean pollution removal for trees and shrubs in GREEN strata, per parish group in Porto (for 2011) (For interpretation of the references to color in this artwork, the reader is referred to the web version of the article). 


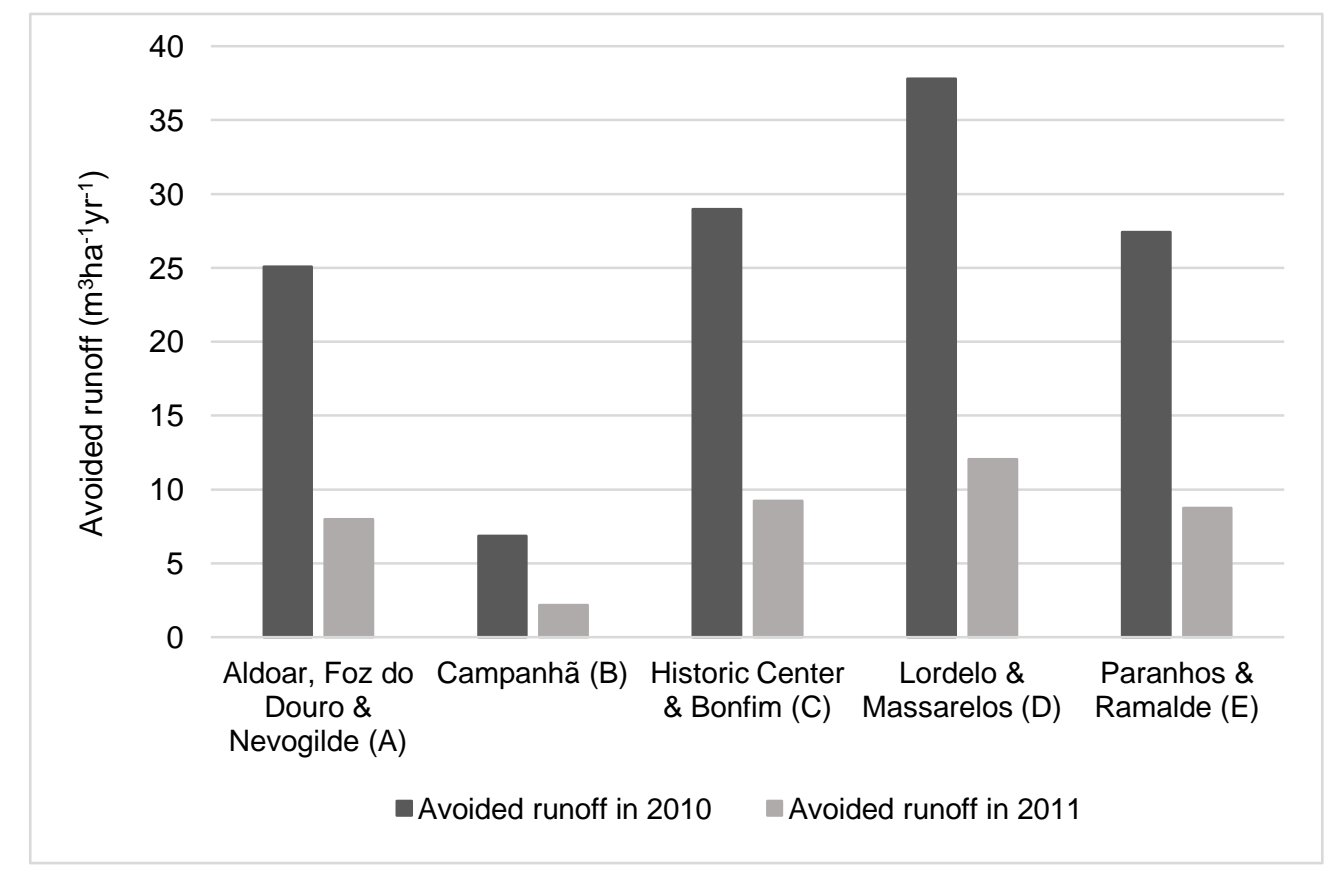

Fig 6: Comparison of avoided runoff in 2010 and 2011 for trees and shrubs in GREEN strata, per parish group in Porto. 


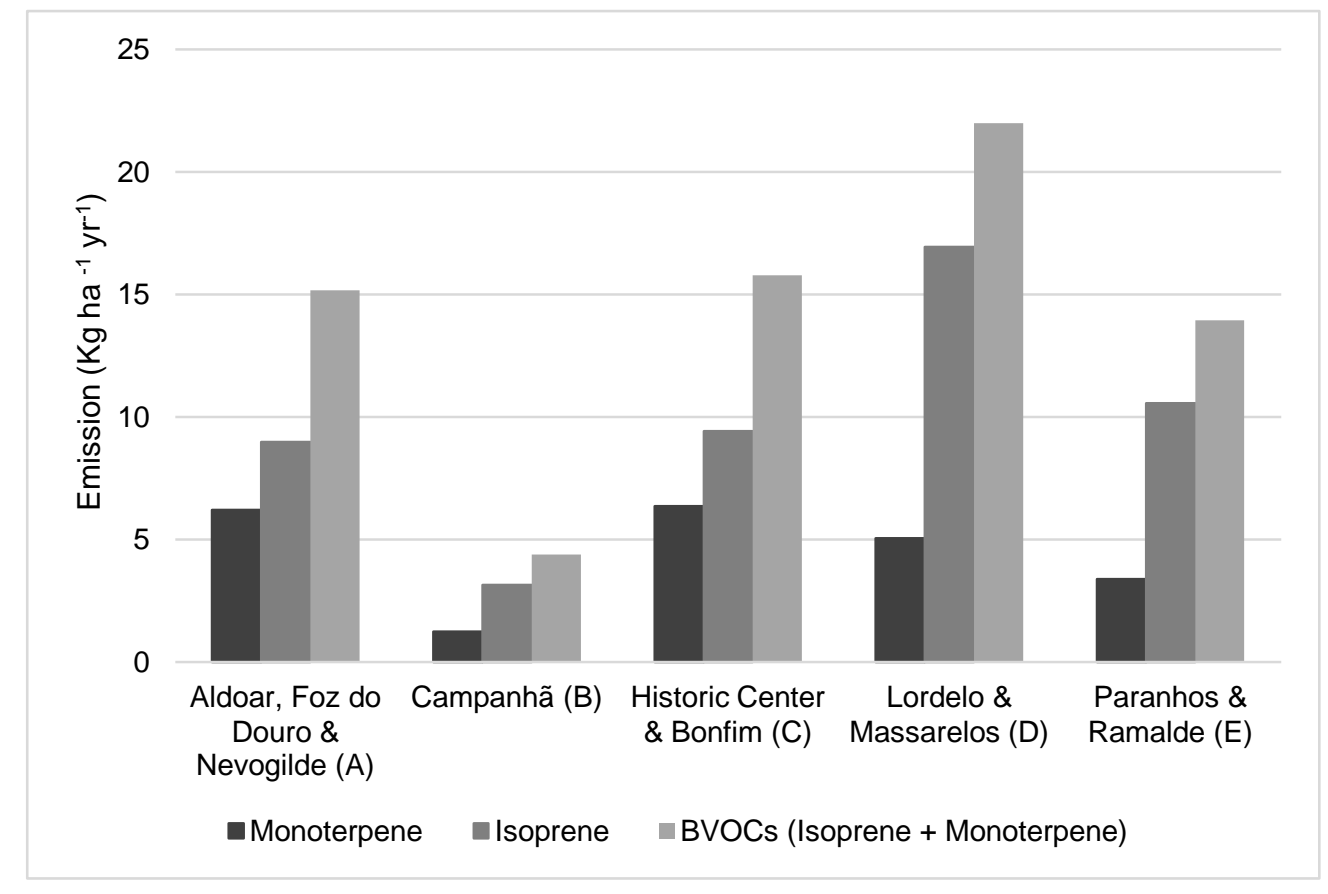

Fig 7: Emissions of Biogenic Volatile Organic Compounds (BVOCs) for trees and shrubs in GREEN strata, per parish group in Porto. 
Table 1: Socioeconomic indicators of parish groups of Porto.

\begin{tabular}{|c|c|c|c|c|c|c|c|c|c|c|c|}
\hline \multirow{2}{*}{ Parish strata } & \multicolumn{2}{|r|}{ Area } & \multicolumn{2}{|c|}{ Number of dwellings } & \multicolumn{2}{|c|}{$\begin{array}{l}\text { Occupation of } \\
\text { dwellings }\end{array}$} & \multicolumn{2}{|c|}{$\begin{array}{l}\text { Building time of } \\
\text { dwellings }{ }^{*}\end{array}$} & \multicolumn{2}{|c|}{$\begin{array}{l}\text { Age of } \\
\text { residents* }\end{array}$} & \multirow{2}{*}{$\begin{array}{c}\text { Pop with } \\
\text { college } \\
\text { degree* } \\
(\%)\end{array}$} \\
\hline & $\begin{array}{l}\text { Total } \\
\text { (ha) }\end{array}$ & $\begin{array}{c}\text { Of } \\
\text { municipality } \\
(\%)\end{array}$ & Total & $\begin{array}{c}\text { In } \\
\text { municipality } \\
(\%)\end{array}$ & $\begin{array}{l}\text { Owner } \\
\text { or co- } \\
\text { owner } \\
(\%)\end{array}$ & $\begin{array}{c}\text { Tenant or } \\
\text { sub-tenant } \\
(\%)\end{array}$ & $\begin{array}{l}\text { Until } \\
1945 \\
(\%)\end{array}$ & $\begin{array}{c}1981- \\
2011(\%)\end{array}$ & $\begin{array}{l}\leq 14 \\
\text { yrs } \\
(\%)\end{array}$ & $\begin{array}{l}\geq 65 \\
\text { yrs } \\
(\%)\end{array}$ & \\
\hline $\begin{array}{l}\text { Aldoar, Foz do } \\
\text { Douro and } \\
\text { Nevogilde (A) }\end{array}$ & 627 & 15,1 & 11280 & 11,4 & 64,5 & 27,7 & 20,1 & 36,9 & 13,8 & 21,4 & 31,9 \\
\hline Campanhã (B) & 804 & 19,4 & 12763 & 12,9 & 36,2 & 56,4 & 48,9 & 13,8 & 12,3 & 23,0 & 8,8 \\
\hline $\begin{array}{l}\text { Historic Center } \\
\text { and Bonfim }(\mathrm{C})\end{array}$ & 853 & 20,6 & 28944 & 29,3 & 42,1 & 51,4 & 51,6 & 11,4 & 9,8 & 27,0 & 21,8 \\
\hline $\begin{array}{l}\text { Lordelo and } \\
\text { Massarelos (D) }\end{array}$ & 559 & 13,5 & 11536 & 11,7 & 52,3 & 40,5 & 32,4 & 19,3 & 13,3 & 20,7 & 26,6 \\
\hline $\begin{array}{l}\text { Paranhos and } \\
\text { Ramalde (E) }\end{array}$ & 1299 & 31,4 & 34146 & 34,6 & 54,4 & 39,3 & 29,7 & 16,5 & 12,4 & 21,8 & 23,2 \\
\hline City Total & 4142 & 100,0 & 98669 & 100,0 & 49,3 & 43,9 & 39,7 & 16,8 & 11,9 & 23,2 & 22,3 \\
\hline
\end{tabular}

* Variables used for GLM multimodel inference (section 2.3) 
Table 2: Comparison of $\mathrm{i}$-Tree Eco results for several cities across the world.

\begin{tabular}{|c|c|c|c|c|c|c|}
\hline City & Country & $\begin{array}{l}\text { Total study } \\
\text { area (ha) }\end{array}$ & $\begin{array}{c}\text { Tree } \\
\text { Cover } \\
(\%) \\
\end{array}$ & $\begin{array}{c}\text { Number of } \\
\text { trees }\end{array}$ & $\begin{array}{c}\text { Trees / } \\
\text { ha }\end{array}$ & Source \\
\hline PORTO & Portugal & 4,091 & 10.6 & 281,359 & 68.8 & \\
\hline New York & USA & $78,949^{a}$ & $21.0^{1}$ & $5,212,000^{1}$ & $65.2^{1}$ & $\begin{array}{l}\text { Nowak et al. (2007); } \\
\text { DCPNY (n.d.) }\end{array}$ \\
\hline Toronto & Canada & $66,140^{c}$ & $26.6^{b}$ & $10,220,000^{b}$ & $160.4^{b}$ & $\begin{array}{l}{ }^{b} \text { Nowak et al. (2013); }{ }^{c} \text { PFR } \\
\text { (n.d.) }\end{array}$ \\
\hline Jersey City & USA & $3,859^{d}$ & $11.5^{1}$ & $136,000^{1}$ & $35.3^{1}$ & $\begin{array}{l}\text { Nowak et al. (2007); }{ }^{d} \text { CJC } \\
\text { (n.d.) }\end{array}$ \\
\hline \multirow[t]{2}{*}{ Edinburgh } & UK & $11,468^{e}$ & $17.0^{e}$ & $638,000^{e}$ & $56.0^{f}$ & ${ }^{\mathrm{e}}$ Hutchings et al. (2012) \\
\hline & & & & & & ${ }^{f}$ Rumble (2015) \\
\hline Glasgow & UK & 17,643 & 15.0 & $20,000,000$ & 112 & Rumble (2015) \\
\hline Wrexham & UK & $3,833^{2}$ & 17.0 & 364,000 & 95 & Rumble (2014) \\
\hline Torbay & UK & $6,375^{g}$ & $11.8^{\mathrm{g}}$ & $818,000^{g}$ & $105.0^{g}$ & $\begin{array}{l}{ }^{f} \text { Rumble }(2015) ;{ }^{g} \text { Rogers } \\
(2011)\end{array}$ \\
\hline Barcelona & Spain & 10,121 & 25.2 & $1,419,823$ & 141 & Chaparro \& Terradas (2009) \\
\hline Berlin & Germany & 89,110 & 42.7 & - & - & Baró et al. (2015) \\
\hline Rotterdam & Netherlands & 27,740 & 12.2 & - & - & Baró et al. (2015) \\
\hline Salzburg & Austria & 6,570 & 28.6 & - & - & Baró et al. (2015) \\
\hline Stockholm & Sweden & 21,580 & 37.5 & - & - & Baró et al. (2015) \\
\hline
\end{tabular}

${ }^{1}$ Information provided automatically by i-Tree Eco software.

${ }^{2}$ Neighboring cities were also considered in this case study

* Refers to total analyzed area in study, except New York, Toronto and Jersey City. In these cases there was no information available, and total study area was assumed to match the city official limits. 
Table 3: I-Tree Eco results for GREEN and GREY strata per parish group. GREEN refers to the main green structure of the city and GREY to the remaining area.

\begin{tabular}{|c|c|c|c|c|c|c|c|c|c|c|c|}
\hline \multirow{2}{*}{$\begin{array}{c}\text { Parish group } \\
\text { Name (stratum id) }\end{array}$} & \multirow{2}{*}{ Sub-stratum } & \multirow{2}{*}{$\begin{array}{c}\text { Stratum } \\
\text { area in } \\
\text { each parish } \\
(\%)\end{array}$} & \multirow{2}{*}{$\begin{array}{l}\text { Trees } \\
\left(\mathrm{n} \mathrm{ha}^{-1}\right)\end{array}$} & \multirow{2}{*}{$\begin{array}{c}\text { Tree } \\
\text { species } \\
\left(\mathrm{n} \mathrm{ha}^{-1}\right)\end{array}$} & \multirow{2}{*}{$\begin{array}{l}\text { Simpson } \\
\text { Index }\end{array}$} & \multirow{2}{*}{$\begin{array}{c}\text { Tree Leaf } \\
\text { Area } \\
\left(\mathrm{m}^{2} \mathrm{ha}^{-1}\right)\end{array}$} & \multirow{2}{*}{$\begin{array}{l}\text { Tree Leaf } \\
\text { Biomass } \\
\left(\mathrm{Kg} \mathrm{ha}^{-1}\right)\end{array}$} & \multirow{2}{*}{$\begin{array}{l}\text { C storage } \\
\left(\mathrm{Kg} \mathrm{ha}^{-1}\right)\end{array}$} & \multirow{2}{*}{$\begin{array}{c}\mathrm{C} \text { net } \\
\text { sequestration } \\
\left(\mathrm{Kg} \mathrm{ha}^{-1} \mathrm{yr}^{-1}\right)\end{array}$} & \multicolumn{2}{|c|}{ Top tree species abundance ( $\mathrm{n}$ ha $\left.{ }^{1}\right)$} \\
\hline & & & & & & & & & & Species & $\mathrm{n} \mathrm{ha}^{-1}$ \\
\hline \multirow{5}{*}{$\begin{array}{l}\text { Aldoar, Foz do Douro } \\
\text { and Nevogilde (A) }\end{array}$} & & & & & & & & & & Pittosporum tobira & 20.5 \\
\hline & GREEN & 45.82 & 190.0 & 41.0 & 0.95 & $14,041.1$ & $1,239.2$ & $16,299.2$ & 627.4 & Populus nigra & 15.9 \\
\hline & & & & & & & & & & Arbutus unedo & 15.9 \\
\hline & & & & & & & & & & Eriobotrya japonica & 5.0 \\
\hline & GREY & 54.18 & 27.6 & 25.1 & 0.98 & $1,120.2$ & 94.2 & $3,029.2$ & 165.1 & Castanea sativa & 2.5 \\
\hline \multirow{6}{*}{ Campanhã (B) } & & & & & & & & & & $\begin{array}{l}\text { Cltrus sinensis } \\
\text { Quercus robur }\end{array}$ & $\begin{array}{c}2.5 \\
29.2\end{array}$ \\
\hline & GREEN & 46.80 & 97.1 & 23.0 & 0.87 & $3,837.7$ & 455.7 & $7,093.6$ & 309.6 & Quercus suber & 14.6 \\
\hline & & & & & & & & & & Actinidia deliciosa & 7.3 \\
\hline & & & & & & & & & & Cupressus sempervirens & 21.6 \\
\hline & GRFY & 5320 & 302 & 108 & & & & & & 'Stricta' & 2.2 \\
\hline & GREY & 53.20 & 30.2 & 10.8 & 0.50 & 490.7 & 73.8 & 426.8 & 65.1 & $\begin{array}{l}\text { Abies nordmanniana } \\
\text { Citrus lemon }\end{array}$ & 2.2 \\
\hline \multirow{4}{*}{$\begin{array}{l}\text { Historic Center and } \\
\text { Bonfim }(\mathrm{C})\end{array}$} & & & & & & & & & & Acacia melanoxylon & 37.7 \\
\hline & GREEN & 26.05 & 167.5 & 47.1 & 0.92 & $16,226.9$ & $1,721.5$ & $24,316.1$ & 788.6 & Magnolia $x$ soulangiana & 22.0 \\
\hline & & & & & & & & & & Camellia japonica & 13.6 \\
\hline & GREY & 73.95 & 1.6 & 1.7 & 0.00 & 118.7 & 8.9 & 51.1 & 8.8 & Ficus carica & 1.6 \\
\hline \multirow{4}{*}{$\begin{array}{l}\text { Lordelo and } \\
\text { Massarelos (D) }\end{array}$} & & & & & & & & & & Weigela sp. & 47.5 \\
\hline & GREEN & 43.60 & 208.0 & 58.0 & 0.90 & $21,149.4$ & $2,129.5$ & $40,579.7$ & $1,218.4$ & Populus nigra 'Italica' & 38.6 \\
\hline & & & & & & & & & & Crataegus laevigata & 13.4 \\
\hline & GREY & 56.40 & 7.6 & 5.1 & 0.67 & $1,402.3$ & 127.9 & 409.8 & 44.6 & $\begin{array}{l}\text { Acer negundo } \\
\text { Prunus lusitanica }\end{array}$ & $\begin{array}{l}5.1 \\
2.5\end{array}$ \\
\hline \multirow{6}{*}{$\begin{array}{l}\text { Paranhos and } \\
\text { Ramalde (E) }\end{array}$} & & & & & & & & & & Populus nigra & 11.8 \\
\hline & GREEN & 35.76 & 133.4 & 41.6 & 0.97 & $15,339.0$ & $1,153.6$ & $21,030.2$ & 786.9 & Quercus suber & 10.5 \\
\hline & & & & & & & & & & Platanus $x$ acerifolia & 8.7 \\
\hline & & & & & & & & & & Pyracantha coccinea & 9.1 \\
\hline & GREY & 64.24 & 31.1 & 18.2 & 0.90 & $1,580.5$ & 104.9 & $2,716.4$ & 179.2 & Nerium oleander & 5.2 \\
\hline & & & & & & & & & & Acer negundo & 2.6 \\
\hline \multirow{3}{*}{ City Total } & & & & & & & & & & Quercus robur & 3.7 \\
\hline & & & 68.8 & 4.3 & & $5,307.6$ & 486.3 & $8,100.7$ & 315.9 & Populus nigra & 2.9 \\
\hline & & & & & & & & & & Quercus suber & 2.7 \\
\hline
\end{tabular}


Table 4: Comparison of models used in GLM multimodel inference. Models with a subscript letter $i$ include an interaction term with the categorical variable: "Type of substratum" which allows to separate the effect between the GREEN or GREY structure in each parish group. The column "Coef. sign" represents the coefficient signs as: positive $\nearrow$, and, negative $\measuredangle$. For models with interactions terms with "Type of substratum" the first sign (on the left) is for green areas and the second (right side) is for the remaining areas.

\begin{tabular}{|c|c|c|c|c|c|c|c|c|}
\hline Response & Model & Explanatory (rates, except null) & Coef. sign & k & $\mathrm{AICc}$ & $\begin{array}{c}\Delta \\
\mathrm{AICc}\end{array}$ & $\mathrm{AICc} W \mathrm{t}$ & $\mathrm{R}^{2}$ adjusted \\
\hline \multirow{9}{*}{$D B H(\mathrm{~cm})$} & $\mathrm{M}_{\mathrm{A} 1}$ & Owner or co-owner & $\nearrow$ & 3 & -38.74 & 0.00 & 0.36 & 0.46 \\
\hline & $\mathrm{M}_{\mathrm{A} 4}$ & Built until 1945 & $\swarrow$ & 3 & -37.81 & 0.93 & 0.23 & 0.41 \\
\hline & $\mathrm{M}_{\mathrm{A} 2}$ & Pop with college degree & $\nearrow$ & 3 & -37.16 & 1.58 & 0.17 & 0.37 \\
\hline & $\mathrm{M}_{0}$ & Null model & $\nearrow$ & 2 & -36.84 & 1.91 & 0.14 & - \\
\hline & $\mathrm{M}_{\mathrm{A3}}$ & Pop with $0-14$ yrs & $\nearrow$ & 3 & -34.77 & 3.97 & 0.05 & 0.2 \\
\hline & $\mathrm{M}_{\mathrm{A1i}}$ & $\begin{array}{l}\text { Owner or co-owner : Type of } \\
\text { substratum }\end{array}$ & フ & 4 & -32.98 & 5.76 & 0.02 & 0.47 \\
\hline & $\mathrm{M}_{\mathrm{A} 4 \mathrm{i}}$ & Built until 1945 : Type of substratum & $\swarrow \swarrow$ & 4 & -32.74 & 6.00 & 0.02 & 0.46 \\
\hline & $\mathrm{M}_{\mathrm{A} 2 \mathrm{i}}$ & $\begin{array}{l}\text { Pop with college degree : Type of } \\
\text { substratum }\end{array}$ & $\pi$ & 4 & -31.32 & 7.42 & 0.01 & 0.38 \\
\hline & $\mathrm{M}_{\mathrm{A3i}}$ & Pop with 0-14 yrs : Type of substratum & $\nearrow$ & 4 & -29.02 & 9.72 & 0.00 & 0.22 \\
\hline \multirow{9}{*}{ Tree density $\left(h a^{-1}\right)$} & $\mathrm{M}_{\mathrm{B} 2 \mathrm{i}}$ & $\begin{array}{l}\text { Pop with college degree : Type of } \\
\text { substratum }\end{array}$ & $\lambda K$ & 4 & 101.42 & 0.00 & 0.95 & 0.95 \\
\hline & $\mathrm{M}_{\mathrm{B} 1 \mathrm{i}}$ & $\begin{array}{l}\text { Owner or co-owner: Type of } \\
\text { substratum }\end{array}$ & $\pi$ & 4 & 107.65 & 6.23 & 0.04 & 0.90 \\
\hline & $\mathrm{M}_{\mathrm{B} 3 \mathrm{i}}$ & $\begin{array}{l}\text { Pop with and }+65 \text { yrs : Type of } \\
\text { substratum }\end{array}$ & $\swarrow \swarrow$ & 4 & 112.12 & 10.70 & 0.00 & 0.85 \\
\hline & $\mathrm{M}_{\mathrm{B} 4 \mathrm{i}}$ & $\begin{array}{l}\text { Building time between } 1981 \text { and } 2011 \text { : } \\
\text { Type of substratum }\end{array}$ & $\nearrow \swarrow$ & 4 & 114.99 & 13.57 & 0.00 & 0.80 \\
\hline & $\mathrm{M}_{0}$ & Null model & $\nearrow$ & 2 & 120.65 & 19.22 & 0.00 & - \\
\hline & $\mathrm{M}_{\mathrm{B} 2}$ & Pop with college degree & $\nearrow$ & 3 & 124.48 & 23.06 & 0.00 & 0.04 \\
\hline & $\mathrm{M}_{\mathrm{B} 1}$ & Owner or co-owner & $\nearrow$ & 3 & 124.59 & 23.17 & 0.00 & 0.03 \\
\hline & $\mathrm{M}_{\mathrm{B} 4}$ & Building time between 1981 and 2011 & $\nearrow$ & 3 & 124.68 & 23.26 & 0.00 & 0.02 \\
\hline & $\mathrm{M}_{\mathrm{B} 3}$ & Pop with and +65 yrs & $\swarrow$ & 3 & 124.83 & 23.41 & 0.00 & 0.01 \\
\hline \multirow{9}{*}{$T L A\left(m_{2} h a^{-1}\right)$} & $M_{D 2 i}$ & $\begin{array}{l}\text { Pop with college degree : Type of } \\
\text { substratum }\end{array}$ & $\pi$ & 4 & 201.42 & 0.00 & 0.93 & 0.89 \\
\hline & $\mathrm{M}_{\mathrm{D} 1 \mathrm{i}}$ & $\begin{array}{l}\text { Owner or co-owner : Type of } \\
\text { substratum }\end{array}$ & $\pi$ & 4 & 207.27 & 5.85 & 0.05 & 0.80 \\
\hline & $M_{D 3 i}$ & $\begin{array}{l}\text { Pop with and }+65 \text { yrs : Type of } \\
\text { substratum }\end{array}$ & $\swarrow \swarrow$ & 4 & 210.54 & 9.12 & 0.01 & 0.72 \\
\hline & $\mathrm{M}_{0}$ & Null model & $\nearrow$ & 2 & 213.14 & 11.72 & 0.00 & - \\
\hline & $M_{D 4 i}$ & $\begin{array}{l}\text { Building time between } 1981 \text { and } 2011 \text { : } \\
\text { Type of substratum }\end{array}$ & $\neg \swarrow$ & 4 & 213.57 & 12.15 & 0.00 & 0.63 \\
\hline & $\mathrm{M}_{\mathrm{D} 2}$ & Pop with college degree & $\nearrow$ & 3 & 216.46 & 15.04 & 0.00 & 0.09 \\
\hline & $M_{D 1}$ & Owner or co-owner & $\nearrow$ & 3 & 216.95 & 15.53 & 0.00 & 0.05 \\
\hline & $\mathrm{M}_{\mathrm{D} 3}$ & Pop with and +65 yrs & $\swarrow$ & 3 & 217.34 & 15.93 & 0.00 & 0.01 \\
\hline & $\mathrm{M}_{\mathrm{D} 4}$ & Building time between 1981 and 2011 & $\pi$ & 3 & 217.38 & 15.96 & 0.00 & 0.00 \\
\hline \multirow{5}{*}{$T L B\left(K g h a^{-1}\right)$} & $M_{E 2 i}$ & $\begin{array}{l}\text { Pop with college degree : Type of } \\
\text { substratum }\end{array}$ & $\nearrow \swarrow$ & 4 & 158.88 & 0.00 & 0.81 & 0.83 \\
\hline & $M_{E 1 i}$ & $\begin{array}{l}\text { Owner or co-owner : Type of } \\
\text { substratum }\end{array}$ & $x$ & 4 & 163.28 & 4.40 & 0.09 & 0.74 \\
\hline & $\mathrm{M}_{\mathrm{E} 3 \mathrm{i}}$ & $\begin{array}{l}\text { Pop with and }+65 \text { yrs : Type of } \\
\text { substratum }\end{array}$ & $x x$ & 4 & 164.24 & 5.36 & 0.06 & 0.71 \\
\hline & $\mathrm{M}_{0}$ & Null model & $\nearrow$ & 2 & 166.35 & 7.47 & 0.02 & - \\
\hline & $\mathrm{M}_{\mathrm{E} 4 \mathrm{i}}$ & $\begin{array}{l}\text { Building time between } 1981 \text { and } 2011 \text { : } \\
\text { Type of substratum }\end{array}$ & $x$ & 4 & 167.82 & 8.94 & 0.01 & 0.59 \\
\hline
\end{tabular}




\begin{tabular}{|c|c|c|c|c|c|c|c|c|}
\hline & $\mathrm{M}_{\mathrm{E} 2}$ & Pop with college degree & $\nearrow$ & 3 & 169.96 & 11.08 & 0.00 & 0.06 \\
\hline & $M_{E 1}$ & Owner or co-owner & $\nearrow$ & 3 & 170.45 & 11.57 & 0.00 & 0.02 \\
\hline & $\mathrm{M}_{\mathrm{E} 3}$ & Pop with and +65 yrs & $\swarrow$ & 3 & 170.63 & 11.74 & 0.00 & 0.00 \\
\hline & $M_{E 4}$ & Building time between 1981 and 2011 & $\nearrow$ & 3 & 170.63 & 11.75 & 0.00 & 0.00 \\
\hline \multirow{9}{*}{ Tree species $\left(h^{-1}\right)$} & $\mathrm{M}_{\mathrm{F} 2 \mathrm{i}}$ & $\begin{array}{l}\text { Pop with college degree : Type of } \\
\text { substratum }\end{array}$ & $\pi$ & 4 & 86.67 & 0.00 & 0.60 & 0.79 \\
\hline & $\mathrm{M}_{\mathrm{F} 1 \mathrm{i}}$ & $\begin{array}{l}\text { Owner or co-owner : Type of } \\
\text { substratum }\end{array}$ & $\pi$ & 4 & 88.54 & 1.87 & 0.24 & 0.75 \\
\hline & $\mathrm{M}_{\mathrm{F} 31}$ & Pop with 0-14 yrs : Type of substratum & $\nearrow$ & 4 & 90.79 & 4.11 & 0.08 & 0.68 \\
\hline & $\mathrm{M}_{0}$ & Null model & $\nearrow$ & 2 & 91.94 & 5.27 & 0.04 & - \\
\hline & $M_{F 4 i}$ & $\begin{array}{l}\text { Building time between } 1981 \text { and } 2011 \text { : } \\
\text { Type of substratum }\end{array}$ & $\nearrow \swarrow$ & 4 & 94.90 & 8.23 & 0.01 & 0.52 \\
\hline & $\mathrm{M}_{\mathrm{F} 2}$ & Pop with college degree & $\nearrow$ & 3 & 95.18 & 8.51 & 0.01 & 0.10 \\
\hline & $\mathrm{M}_{\mathrm{F} 1}$ & Owner or co-owner & $\nearrow$ & 3 & 95.26 & 8.59 & 0.01 & 0.09 \\
\hline & $\mathrm{M}_{\mathrm{F} 4}$ & Building time between 1981 and 2011 & $\nearrow$ & 3 & 95.76 & 9.09 & 0.01 & 0.05 \\
\hline & $\mathrm{M}_{\mathrm{F3}}$ & Pop with $0-14$ yrs & $\nearrow$ & 3 & 95.95 & 9.28 & 0.01 & 0.03 \\
\hline \multirow{9}{*}{ Simpson Index } & $M_{G 4 i}$ & Built until 1945 : Type of substratum & $\swarrow \swarrow$ & 4 & 5.07 & 0.00 & 0.72 & 0.77 \\
\hline & $M_{0}$ & Null model & $\nearrow$ & 2 & 9.54 & 4.47 & 0.08 & 0.00 \\
\hline & $\mathrm{M}_{\mathrm{G} 4}$ & Built until 1945 & $\swarrow$ & 3 & 9.78 & 4.71 & 0.07 & 0.33 \\
\hline & $\mathrm{M}_{\mathrm{G} 3}$ & Pop with $0-14$ yrs & $\lambda$ & 3 & 10.30 & 5.24 & 0.05 & 0.30 \\
\hline & $\mathrm{M}_{\mathrm{G} 1}$ & Owner or co-owner & $\nearrow$ & 3 & 11.00 & 5.93 & 0.04 & 0.25 \\
\hline & $\mathrm{M}_{\mathrm{G} 3 \mathrm{i}}$ & Pop with 0-14 yrs : Type of substratum & $\pi$ & 4 & 12.49 & 7.42 & 0.02 & 0.52 \\
\hline & $\mathrm{M}_{\mathrm{G} 2}$ & Pop with college degree & $\nearrow$ & 3 & 12.90 & 7.83 & 0.01 & 0.09 \\
\hline & $\mathrm{M}_{\mathrm{G} 1 \mathrm{i}}$ & $\begin{array}{l}\text { Owner or co-owner : Type of } \\
\text { substratum }\end{array}$ & $\nearrow$ & 4 & 13.95 & 8.88 & 0.01 & 0.44 \\
\hline & $M_{\mathrm{G} 2 \mathrm{i}}$ & $\begin{array}{l}\text { Pop with college degree : Type of } \\
\text { substratum }\end{array}$ & $\pi$ & 4 & 16.57 & 11.50 & 0.00 & 0.28 \\
\hline \multirow{9}{*}{ Tree condition } & $\mathrm{M}_{\mathrm{C} 4}$ & Building time between 1981 and 2011 & $\nearrow$ & 3 & -33.37 & 0.00 & 0.50 & 0.49 \\
\hline & $\mathrm{M}_{0}$ & Null model & $\nearrow$ & 2 & -31.01 & 2.36 & 0.15 & 0.00 \\
\hline & $\mathrm{M}_{\mathrm{C} 4 \mathrm{i}}$ & $\begin{array}{l}\text { Building time between } 1981 \text { and } 2011 \text { : } \\
\text { Type of substratum }\end{array}$ & $\nearrow$ & 4 & -30.79 & 2.57 & 0.14 & 0.63 \\
\hline & $\mathrm{M}_{\mathrm{C3}}$ & Pop with 0-14 yrs & $\nearrow$ & 3 & -29.70 & 3.67 & 0.08 & 0.26 \\
\hline & $\mathrm{M}_{\mathrm{C} 1}$ & Owner or co-owner & $\lambda$ & 3 & -28.74 & 4.63 & 0.05 & 0.18 \\
\hline & $\mathrm{M}_{\mathrm{C} 3 \mathrm{i}}$ & Pop with 0-14 yrs : Type of substratum & $\pi$ & 4 & -28.18 & 5.19 & 0.04 & 0.53 \\
\hline & $\mathrm{M}_{\mathrm{C} 2}$ & Pop with college degree & $\nearrow$ & 3 & -27.55 & 5.82 & 0.03 & 0.08 \\
\hline & $\mathrm{M}_{\mathrm{C} 1 \mathrm{i}}$ & $\begin{array}{l}\text { Owner or co-owner : Type of } \\
\text { substratum }\end{array}$ & $\pi$ & 4 & -25.71 & 7.66 & 0.01 & 0.39 \\
\hline & $\mathrm{M}_{\mathrm{C} 2 \mathrm{i}}$ & $\begin{array}{l}\text { Pop with college degree : Type of } \\
\text { substratum }\end{array}$ & $\nearrow$ & 4 & -23.42 & 9.95 & 0.00 & 0.24 \\
\hline
\end{tabular}


Table 5: Comparison of models used in GAM multimodel inference.

\begin{tabular}{|c|c|c|c|c|c|c|c|}
\hline Response & Model & Explanatory & k & AICc & $\triangle \mathrm{AlCc}$ & AIC Wt & $\mathrm{R}^{2}$ adjusted \\
\hline \multirow[t]{6}{*}{ Stored C $\left(\mathrm{Kg} \mathrm{ha}^{-1}\right)$} & MA3 & Tree DBH & 12.58 & 811.04 & 0.00 & 1.00 & 0.72 \\
\hline & MA5 & Tree Leaf Biomass & 2.00 & 857.13 & 46.09 & 0.00 & 0.63 \\
\hline & MA2 & Tree Density & 2.69 & 1057.43 & 246.39 & 0.00 & 0.27 \\
\hline & MA4 & Tree Condition & 7.64 & 1099.63 & 288.59 & 0.00 & 0.16 \\
\hline & MA1 & Shading Factor & 2.00 & 1130.89 & 319.85 & 0.00 & 0.03 \\
\hline & M0 & Null Model & 1.00 & 1136.91 & 325.87 & 0.00 & - \\
\hline \multirow[t]{6}{*}{ C Net Sequestration (Kg yr $\left.r^{-1} a^{-1}\right)$} & MB5 & Tree Leaf Biomass & 2.21 & 735.26 & 0.00 & 0.98 & 0.46 \\
\hline & MB3 & Tree DBH & 10.71 & 743.55 & 8.29 & 0.02 & 0.47 \\
\hline & MB2 & Tree Density & 2.87 & 748.98 & 13.71 & 0.00 & 0.44 \\
\hline & MB4 & Tree Condition & 7.83 & 853.43 & 118.17 & 0.00 & 0.17 \\
\hline & MB1 & Shading Factor & 2.55 & 882.79 & 147.52 & 0.00 & 0.04 \\
\hline & M0 & Null Model & 1.00 & 892.39 & 157.12 & 0.00 & - \\
\hline Tree Leaf Area $\left(m_{2} h a^{-1}\right)$ & MC3 & Tree DBH & 8.63 & 820.54 & 0.00 & 1.00 & 0.51 \\
\hline \multirow{4}{*}{$\begin{array}{l}\text { (proxy for pollution removal and } \\
\text { avoided runoff) }\end{array}$} & MC2 & Tree Density & 2.92 & 926.56 & 106.02 & 0.00 & 0.25 \\
\hline & MC4 & Tree Condition & 4.76 & 961.97 & 141.43 & 0.00 & 0.15 \\
\hline & MC1 & Shading Factor & 3.15 & 997.17 & 176.63 & 0.00 & 0.01 \\
\hline & Mo & Null Model & 1.00 & 998.54 & 178.00 & 0.00 & - \\
\hline
\end{tabular}

